\title{
Observations of hydroxyl and peroxy radicals and the impact of BrO at Summit, Greenland in 2007 and 2008
}

\author{
J. Liao ${ }^{1}$, L. G. Huey ${ }^{1}$, D. J. Tanner ${ }^{1}$, N. Brough ${ }^{2}$, S. Brooks ${ }^{3}$, J. E. Dibb ${ }^{4}$, J. Stutz ${ }^{5}$, J. L. Thomas ${ }^{5, *}$, B. Lefer ${ }^{6}$, \\ C. Haman ${ }^{6}$, and K. Gorham ${ }^{7}$ \\ ${ }^{1}$ School of Earth and Atmospheric Sciences, Georgia Institute of Technology, Atlanta, Georgia, USA \\ ${ }^{2}$ British Antarctic Survey, Natural Environment Research Council, Cambridge, UK \\ ${ }^{3}$ NOAA Atmospheric Turbulence and Diffusion Division, TN, USA \\ ${ }^{4}$ Climate Change Research Center, Institute for the Study of Earth, Oceans and Space, University of New Hampshire, \\ Durham, NH, USA \\ ${ }^{5}$ University of California Los Angeles, Department of Atmosphere Ocean Science, Los Angeles, CA, USA \\ ${ }^{6}$ Department of Geosciences, University of Houston, TX, USA \\ ${ }^{7}$ Chemistry, University of California, Irvine, California, USA \\ *now at: UPMC Univ. Paris 06; Université Versailles St-Quentin; CNRS/INSU, UMR8190; LATMOS-IPSL, Paris, France
}

Received: 6 April 2011 - Published in Atmos. Chem. Phys. Discuss.: 26 April 2011

Revised: 4 August 2011 - Accepted: 7 August 2011 - Published: 23 August 2011

\begin{abstract}
The Greenland Summit Halogen- $\mathrm{HO}_{\mathrm{x}}$ (GSHOX) Campaign was performed in spring 2007 and summer 2008 to investigate the impact of halogens on $\mathrm{HO}_{\mathrm{x}}$ $\left(=\mathrm{OH}+\mathrm{HO}_{2}\right)$ cycling above the Greenland Ice Sheet. Chemical species including hydroxyl and peroxy radicals $\left(\mathrm{OH}\right.$ and $\left.\mathrm{HO}_{2}+\mathrm{RO}_{2}\right)$, ozone $\left(\mathrm{O}_{3}\right)$, nitrogen oxide (NO), nitric acid $\left(\mathrm{HNO}_{3}\right)$, nitrous acid (HONO), reactive gaseous mercury (RGM), and bromine oxide ( $\mathrm{BrO})$ were measured during the campaign. The median midday values of $\mathrm{HO}_{2}+\mathrm{RO}_{2}$ and $\mathrm{OH}$ concentrations observed by chemical ionization mass spectrometry (CIMS) were $2.7 \times 10^{8}$ molec cm $\mathrm{cm}^{-3}$ and $3.0 \times 10^{6} \mathrm{molec} \mathrm{cm}^{-3}$ in spring 2007, and $4.2 \times 10^{8}$ molec $\mathrm{cm}^{-3}$ and $4.1 \times 10^{6}$ molec cm$^{-3}$ in summer 2008. A basic photochemical 0-D box model highly constrained by observations of $\mathrm{H}_{2} \mathrm{O}, \mathrm{O}_{3}, \mathrm{CO}$, $\mathrm{CH}_{4}, \mathrm{NO}$, and $\mathrm{J}$ values predicted $\mathrm{HO}_{2}+\mathrm{RO}_{2}(R=0.90$, slope $=0.87$ in 2007; $R=0.79$, slope $=0.96$ in 2008) reasonably well and under predicted $\mathrm{OH}(R=0.83$, slope $=0.72$ in 2007; $R=0.76$, slope $=0.54$ in 2008). Constraining the model to HONO observations did not significantly improve the ratio of $\mathrm{OH}$ to $\mathrm{HO}_{2}+\mathrm{RO}_{2}$ and the correlation between predictions and observations. Including bromine chemistry in the model constrained by observations of $\mathrm{BrO}$ improved the correlation between observed and predicted $\mathrm{HO}_{2}+\mathrm{RO}_{2}$ and $\mathrm{OH}$, and brought the average hourly $\mathrm{OH}$ and $\mathrm{HO}_{2}+\mathrm{RO}_{2}$
\end{abstract}

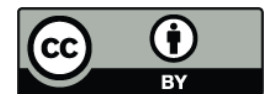

Correspondence to: L. G. Huey

(greg.huey@eas.gatech.edu) predictions closer to the observations. These model comparisons confirmed our understanding of the dominant $\mathrm{HO}_{\mathrm{x}}$ sources and sinks in this environment and indicated that $\mathrm{BrO}$ impacted the $\mathrm{OH}$ levels at Summit. Although, significant discrepancies between observed and predicted $\mathrm{OH}$ could not be explained by the measured BrO. Finally, observations of enhanced RGM were found to be coincident with under prediction of $\mathrm{OH}$.

\section{Introduction}

Summit, Greenland $\left(72^{\circ} 34^{\prime} \mathrm{N}, 38^{\circ} 29^{\prime} \mathrm{W}\right.$, alt $\left.=3.3 \mathrm{~km}\right)$ is located in the middle of the Greenland Ice Sheet and has been the site of a series of scientific studies beginning with ice coring in the 1980s (e.g. Hammer et al., 1980; Mayewski and Bender, 1995). In more recent years, the interaction between photochemically active species in the snowpack and the overlying atmosphere has been studied in detail at Summit and other polar stations (e.g. Dibb and Jaffrezo, 1997; Grannas et al., 2007; Jones et al., 2008; Davis et al., 2001; Huey et al., 2004). Elevated levels of species emitted from surface snow such as nitric oxide $(\mathrm{NO})$, formaldehyde $\left(\mathrm{CH}_{2} \mathrm{O}\right)$, and hydrogen peroxide $\left(\mathrm{H}_{2} \mathrm{O}_{2}\right)$ have been observed over sunlit snow in a series of campaigns (Dibb et al., 2002, 2004; Honrath et al., 1999, 2002; Hutterli et al., 1999, 2001, 2004; Davis et al., 2001; Slusher et al., 2002; Helmig et al., 2008). Snowpack emissions of radical precursors (nitrous acid (HONO),

Published by Copernicus Publications on behalf of the European Geosciences Union. 
$\mathrm{H}_{2} \mathrm{O}_{2}$, and $\left.\mathrm{CH}_{2} \mathrm{O}\right)$ and $\mathrm{NO}_{\mathrm{x}}\left(\mathrm{NO}+\mathrm{NO}_{2}\right)$ have the potential to significantly enhance $\mathrm{HO}_{\mathrm{x}}$ (hydroxyl $(\mathrm{OH})+$ hydroperoxyl $\left(\mathrm{HO}_{2}\right)$ radicals) photochemistry in these locations (e.g. Yang et al., 2002; Chen et al., 2001).

The $\mathrm{OH}$ and peroxy radicals $\left(\mathrm{HO}_{2}+\mathrm{RO}_{2}\right)$ have been measured in a few polar locations and the concentrations vary based on the radical sources as well as environmental conditions. The daytime mean value of $\mathrm{OH}$ observed at Palmer station $\left(64^{\circ} 46^{\prime} \mathrm{S}, 64^{\circ} 3.0^{\prime} \mathrm{W}\right)$ in Antarctica was $3 \times 10^{5} \mathrm{molec}^{-3}$ in austral summer (Jefferson et al., 1998). The low OH levels were found to be consistent with the high solar zenith angle, extensive cloud coverage, no snow coverage, and low $\mathrm{NO}_{\mathrm{x}}$ levels (typically near detection limits of 2-4 pptv) (Jefferson et al., 1998). OH concentrations observed at South Pole were unexpectedly high, with an average value of $2.0( \pm 0.9) \times 10^{6}$ molecule $\mathrm{cm}^{-3}$ in November and December from three field campaigns ISCAT 98, ISCAT 00 and ANTCI 03 (Mauldin et al., 2001, 2004, 2010; Grannas et al., 2007). The high OH levels at South Pole were due to low boundary layer height and snowpack emissions that gave high levels of $\mathrm{NO}_{\mathrm{x}}$ and to a lesser extent formaldehyde (Davis et al., 2001; Hutterli et al., 2004). A photochemical model constrained to $\mathrm{CH}_{2} \mathrm{O}$ and $\mathrm{H}_{2} \mathrm{O}_{2}$ measurements predicted $\mathrm{OH}$ levels with a median modeled to observed (M/O) ratio of 1.27 (Chen et al., 2004). However, the $\mathrm{M} / \mathrm{O}$ ratio for $\mathrm{OH}$ was found to vary with $\mathrm{NO}$ levels at South Pole (Chen et al., 2001, 2004). The model over predicted $\mathrm{OH}$ significantly at low $\mathrm{NO}(\mathrm{NO}<50 \mathrm{pptv} ; \mathrm{M} / \mathrm{O}>1.5)$ and high $\mathrm{NO}(\mathrm{NO}>150 \mathrm{pptv} ; \mathrm{M} / \mathrm{O}=1.5)$ levels but agreed better at moderate levels of NO (Chen et al., 2004). Sjostedt et al. (2007) measured $\mathrm{OH}$ (mean $6.3 \times 10^{6} \mathrm{molec} \mathrm{cm}^{-3}$ ) and $\mathrm{HO}_{2}+\mathrm{RO}_{2}$ (mean $2.8 \times 10^{8}$ molec $\mathrm{cm}^{-3}$ ) levels at Summit, Greenland during summer 2003. The observed $\mathrm{HO}_{2}+\mathrm{RO}_{2}$ levels agreed well with the model predictions, although the measured $\mathrm{OH}$ levels were elevated compared to the predictions (Sjostedt et al., 2007; Chen et al., 2007). Sjostedt et al. (2007) suggested that halogen may be present at Summit, perturbing the $\mathrm{HO}_{\mathrm{x}}$ cycling and enhancing $\mathrm{OH}$ levels. In contrast, a later study at Halley Bay, Antarctica $\left(75^{\circ} 35^{\prime} \mathrm{S}\right.$, $26^{\circ} 19^{\prime} \mathrm{W}$ ) found average $\mathrm{OH}$ levels of $3.9 \times 10^{5} \mathrm{molec}^{-3}$ in February with typical maximum (local noontime) levels of $7.9 \times 10^{5}$ molec cm $^{-3}$ (Bloss et al., 2007, 2010). The OH levels at Halley Bay were slightly higher than measured at Palmer station in the same season of the year but significantly lower than observed at South Pole. The low levels of $\mathrm{OH}$ were surprising as mean diurnal $\mathrm{NO}$ levels of up to $\sim 14$ pptv and significant iodide oxide (IO) and bromine oxide (BrO) levels of up to $\sim 7 \mathrm{pptv}$ and $\sim 9$ pptv were observed. A photochemical box model including halogen reactions significantly over predicted observed levels of $\mathrm{OH}$ and $\mathrm{HO}_{2}$, although the model well predicted the mean levels and diurnal patterns of $\mathrm{NO}_{\mathrm{x}}\left(\mathrm{NO}\right.$ and $\mathrm{NO}_{2}$ ) (Bloss et al., 2007, 2010). The mean daily maximum M/O ratio of $\mathrm{OH}$ was 3.8 and of $\mathrm{HO}_{2}$ was 2.8. The mean observed $\mathrm{HO}_{2}$ to $\mathrm{OH}$ ratio of 46 was in good agreement with the mean predicted value of 44 from the model considering bromine and iodine chemistry, and no elevated $\mathrm{OH}$ was observed.

Prior to the GSHOX campaign, there was only indirect evidence that BrO may exist at Summit, Greenland. Although the overall reservoir of bromine at Summit is much less than in the coastal Arctic where ozone depletion events (ODEs) are typically observed, vertical profiles of ozone obtained from balloon borne sensors have demonstrated that ozone in the boundary layer is consistently depleted relative to the air above (Helmig et al., 2002). However, the reaction of $\mathrm{NO}\left(\sim 20\right.$ pptv) and $\mathrm{RO}_{2}\left(\sim 10^{8}\right.$ molec $\left.\mathrm{cm}^{-3}\right)$ in the boundary layer at Summit should give a local ozone production of $\sim 2$ ppbv day ${ }^{-1}$ (Sjostedt et al., 2007). This type of ozone production is evident in the $\mathrm{NO}_{\mathrm{x}}\left(\mathrm{NO}+\mathrm{NO}_{2}\right)$ rich South Pole boundary layer (Crawford et al., 2001) where boundary layer ozone is elevated relative to the air above (Helmig et al., 2002). In addition, mercury oxidation in snow has been observed at Summit, Greenland (Faïn et al., 2008, Brooks et al., 2011). As $\mathrm{Br}+\mathrm{Hg}^{0}$ (GEM) $\rightarrow \mathrm{Hg}^{2+}$ (RGM) is the only well established reaction that can initiate such rapid conversion of gaseous element mercury (GEM) to reactive gaseous mercury (RGM) (Ariya et al., 2002; Donohoue et al., 2006), depleted GEM and elevated RGM may be a signature of active bromine chemistry as RGM is a relatively short lived species (Steffen et al., 2008).

High levels (up to 30-40 pptv) of $\mathrm{BrO}$ are typically found in the polar marine boundary layer near large sources of halides during ODEs (Tuckermann et al., 1997; Hausmann and Platt, 1994; Saiz-lopez et al., 2007; Liao et al, 2011a). However, significant levels of $\mathrm{BrO}$ have been observed in a variety of other marine locations. For example, $\mathrm{BrO}$ was observed in the tropical marine boundary layer within the Cape Verde archipelago by Read et al. (2008) with an average daytime level of $2.5 \mathrm{pptv}$. Up to $\sim 7 \mathrm{pptv}$ of $\mathrm{BrO}$ was observed in the mid-latitude marine boundary at Roscoff, France $\left(48.7^{\circ} \mathrm{N}, 4.0^{\circ} \mathrm{W}\right)$ (Mahajan et al., 2009) and at the Mace Head Atmospheric Research Station, Ireland $\left(53.33^{\circ} \mathrm{N}, 9.90^{\circ} \mathrm{W}\right)$ (Saiz-lopez et al., 2006).

To investigate the hypothesis that $\mathrm{BrO}$ is present at Summit and that it impacts $\mathrm{HO}_{x}$ photochemistry, a suite of instruments were used to measure $\mathrm{OH}, \mathrm{HO}_{2}+\mathrm{RO}_{2}, \mathrm{BrO}$ and other species at Summit, Greenland in spring 2007 and summer 2008. The observations of $\mathrm{OH}$ and $\mathrm{HO}_{2}+\mathrm{RO}_{2}$, and their comparison to photochemical models are presented in this paper. The $\mathrm{BrO}$ observations and the associated snowpack chemistry are discussed by Stutz et al. (2011) and Thomas et al. (2011), respectively.

\section{Methods}

A comprehensive collection of instruments were used at Summit, Greenland during May-June 2007 and June-July 2008 to measure trace gases and radicals, aerosols, actinic fluxes, and meteorological parameters. Table 1 provides a 
Table 1. Summary of the measurements at Summit, Greenland 2007-2008.

\begin{tabular}{|c|c|c|c|c|}
\hline $\begin{array}{l}\text { Species and } \\
\text { parameters }\end{array}$ & Instrument & Uncertainty & Institution & Reference \\
\hline $\mathrm{O}_{3}$ & UV absorption ozone analyzer & $< \pm 5 \%$ & Ga. Tech & \\
\hline NO & Chemilluminesent gas analyzer & $\pm 10 \%$ & Ga. Tech & Ryerson et al. (2000) \\
\hline $\mathrm{CO}$ & Canister/GC & $< \pm 5 \%$ & UCI & Swanson et al. (2002) \\
\hline $\mathrm{CH}_{4}$ & Canister/GC & $< \pm 5 \%$ & UCI & Swanson et al. (2002) \\
\hline NMHC & Canister/GC & $< \pm 5 \%$ & UCI & Swanson et al. (2002) \\
\hline $\mathrm{OH}$ & CIMS & $\pm 30 \%$ & Ga. Tech & Sjostedt et al. (2007) \\
\hline $\mathrm{HO}_{2}+\mathrm{RO}_{2}$ & CIMS & $\pm 35 \%$ & Ga. Tech & Sjostedt et al. (2007) \\
\hline $\mathrm{BrO}$ & CIMS & $\pm 30 \%-36 \%$ & Ga. Tech & Liao et al. (2011a) \\
\hline $\mathrm{BrO}$ & DOAS & $\pm 10 \%$ & UCLA & Stutz et al. (2011) \\
\hline SMPS_N & SMPS/CPC & $\pm 10 \%$ & $\mathrm{UNH}$ & Ziemba et al. (2010) \\
\hline SMPS_S & SMPS/CPC & $\pm 10 \%$ & UNH & Ziemba et al. (2010) \\
\hline GEM & Tekran & $\pm 2 \%$ & NOAA & Brooks et al. (2011) \\
\hline RGM & Tekran & $\pm 5 \%$ & NOAA & Brooks et al. (2011) \\
\hline FPM & Tekran & $\pm 5 \%$ & NOAA & Brooks et al. (2011) \\
\hline $\mathrm{HNO}_{3}$ & Mist Chamber & $\pm 15 \%-20 \%$ & $\mathrm{UNH}$ & Dibb et al. (1998) \\
\hline Soluble Bromine & Mist Chamber & $\pm 15 \%-20 \%$ & UNH & Dibb et al. (1998) \\
\hline HONO & Mist Chamber & $\pm 15 \%-20 \%$ & UNH & Dibb et al. (1998) \\
\hline Actinic Flux & SAFS & $\pm 10 \%$ & U. Houston & Shetter and Müller (1999) \\
\hline Temperature & F-Thermocouples & $\pm 0.5^{\circ} \mathrm{C}$ & U. Houston & Haman et al. (2011) \\
\hline WS/WD & AWS/Digital compass & & U. Houston & Haman et al. (2011) \\
\hline
\end{tabular}

summary of the measurements during the campaign. The details of measurement techniques not specifically summarized are presented in the references in Table 1. Most of the measurements were located in a satellite camp $\sim 1 \mathrm{~km}$ to the south of the main station. The layout of the experiment is shown in Fig. 1.

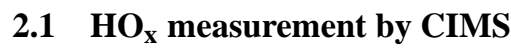

The chemical ionization mass spectrometry (CIMS) instrument to measure $\mathrm{HO}_{\mathrm{x}}\left(\mathrm{OH}\right.$ and sum of $\left.\mathrm{HO}_{2}+\mathrm{RO}_{2}\right)$ is nearly identical to that used to measure $\mathrm{HO}_{\mathrm{x}}$ in 2003 (Sjostedt, 2006 and Sjostedt et al., 2007). The basic methods are based on the work of Tanner et al. (1997). The CIMS was calibrated for $\mathrm{OH}$ and $\mathrm{HO}_{2}$. Because many of the simple $\mathrm{RO}_{2}$ species (e.g. $\mathrm{CH}_{3} \mathrm{O}_{2}$ ) are efficiently converted to $\mathrm{HO}_{2}$ by this method (Edwards et al., 2003), we assumed that the sensitivities for $\mathrm{RO}_{2}$ were the same as for $\mathrm{HO}_{2}$. The CIMS was located in the satellite camp (Fig. 1) and the inlet was about $1.5 \mathrm{~m}$ above the snow surface. The dominant uncertainty in the $\mathrm{OH}$ and $\mathrm{HO}_{2}+\mathrm{RO}_{2}$ measurements is the accuracy of the calibration source (Sjostedt et al., 2007). The combined uncertainties are estimated to be $\sim 30 \%$ for $\mathrm{OH}$ measurements and $\sim 35 \%$ for $\mathrm{HO}_{2}+\mathrm{RO}_{2}$ measurements. The calibration standards for both $\mathrm{OH}$ and $\mathrm{HO}_{2}$ measurements are produced from the photolysis of ambient water vapor, consequently, the uncertainty in the ratio of observed $\mathrm{OH}$ to $\mathrm{HO}_{2}+\mathrm{RO}_{2}$ is smaller than the absolute uncertainties.

\subsection{BrO measurement by CIMS}

The CIMS used to measure BrO levels at Summit is essentially identical to the low pressure CIMS systems used to measure halogens on the NASA DC-8 and NOAA P3 aircrafts during the ARCTAS and ARCPAC campaigns (Neuman et al., 2010), and at Barrow, Alaska during the OASIS 2009 campaign (Liao et al., 2011a). The details of the instrument and air sampling inlet are described in (Liao et al., 2011a) and only significant differences are described here.

$\mathrm{SF}_{6}^{-}$was used as a reagent ion to ionize $\mathrm{BrO}$ and other species such as $\mathrm{SO}_{2}$.

$$
\begin{aligned}
& \mathrm{SO}_{2}+\mathrm{SF}_{6}^{-} \rightarrow \mathrm{F}_{2} \mathrm{SO}_{2}^{-}+\mathrm{SF}_{4} \\
& \mathrm{BrO}+\mathrm{SF}_{6}^{-} \rightarrow \mathrm{BrO}^{-}+\mathrm{SF}_{6} \\
& \mathrm{Br}_{2}+\mathrm{SF}_{6}^{-} \rightarrow \mathrm{Br}_{2}^{-}+\mathrm{SF}_{6}
\end{aligned}
$$

The charge transfer reaction of $\mathrm{SF}_{6}^{-}$with $\mathrm{BrO}$ (Reaction $\mathrm{R} 2$ ) was observed for the first time as part of this work. The rate constant for this reaction was determined relative to that of $\mathrm{SF}_{6}^{-}$with $\mathrm{Br}_{2}$ (Reaction R3) (Streit, 1982). $\mathrm{BrO}$ was synthesized from the reaction of $\mathrm{O}\left({ }^{3} \mathrm{P}\right)$ with $\mathrm{Br}_{2}$ in excess ozone as described in Liao et al. (2011a). The ratio of the rate constant for Reaction (R3) to Reaction (R2) was determined to be $1.0 \pm 25 \%$ in the laboratory. The rate constant for Reaction (R2) derived from this work is $(5 \pm 2) \times 10^{-10}$ molec cm $^{-3} \mathrm{~s}^{-1}$. 


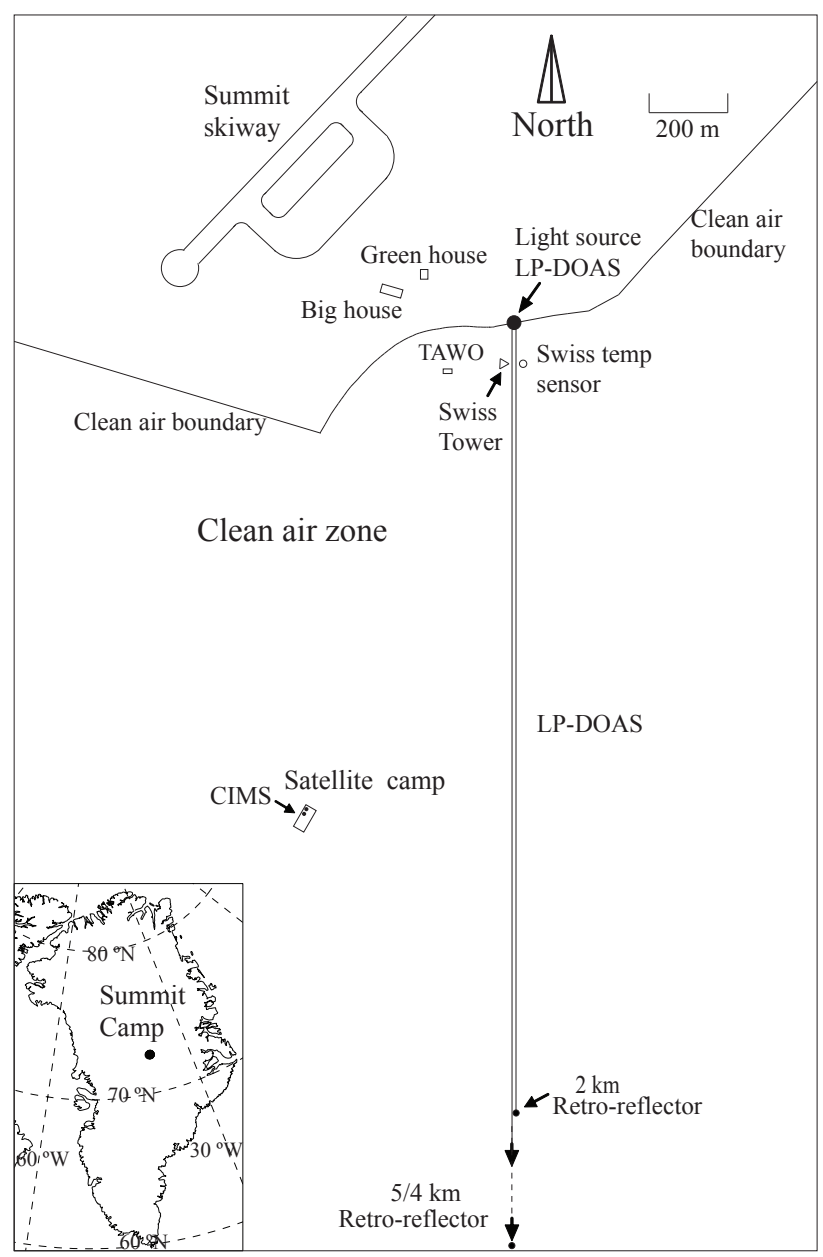

Fig. 1. The layout of the CIMS and LP-DOAS instruments in the Summit campaign.

$\mathrm{SO}_{2}$ was used as our primary calibration gas for determining the sensitivity of the CIMS system in the field (Kim et al., 2007; Slusher et al., 2001) and as a proxy to track the sensitivity of $\mathrm{BrO}$. The ratio of the sensitivity of $\mathrm{BrO}$ to that of $\mathrm{SO}_{2}$ was determined in the laboratory after the campaign as a function of dew point (dewpt). The average sensitivity of $\mathrm{SO}_{2}$ was $\sim 4 \mathrm{~Hz} \mathrm{pptv}^{-1}$ in 2007 and $\sim 60 \mathrm{~Hz} \mathrm{pptv}^{-1}$ in 2008 summit campaign. The sensitivity ratio of $\mathrm{SO}_{2}$ to $\mathrm{BrO}$ was determined as Eq. (1)

$\underline{\mathrm{SO}_{2}}=\left\{\begin{array}{l}\left.0.76-0.096 \times \text { dewpt }-0.00154 \times \text { dewpt (dewpt }>-35^{\circ} \mathrm{C}\right) \\ 2.2\end{array}\right.$

The background signal level of BrO during the 2007 Summit campaign was determined by periodically scrubbing the sampled air with an active carbon filter, similar to that used before for removal of $\mathrm{SO}_{2}, \mathrm{HO}_{2} \mathrm{NO}_{2}$, and $\mathrm{HNO}_{3}$. In 2008 the background was determined by using glass wool because it was found to effectively remove halogen species (Neuman et al., 2010).
The detection limits of $\mathrm{BrO}$ measurements are estimated to be $\sim 1.8$ pptv in 2007 and $\sim 0.7$ pptv in 2008. Considering the uncertainty in $\mathrm{SO}_{2}$ standard concentration $(\sim 10 \%)$, the uncertainties in the sensitivity ratios between $\mathrm{BrO}$ and $\mathrm{Br}_{2}$ $(\sim 25 \%)$ and between $\mathrm{Br}_{2}$ and $\mathrm{SO}_{2}(\sim 5 \%)$, the total uncertainty in $\mathrm{BrO}$ measurements is estimated to be $\sim 36 \%$. The concentrations of $\mathrm{BrO}$ at Summit in spring 2007 and summer 2008 were often near the detection limits of both instruments (detection limit of LP DOAS $=0.5-2$ pptv; detection limit of CIMS $=\sim 1-2$ pptv). Moreover, the measurements of $\mathrm{BrO}$ at Summit were the earliest applications of CIMS to measure ambient $\mathrm{BrO} . \mathrm{SF}_{6}^{-}$was used as the reagent ion to detect $\mathrm{BrO}$ at that time. After these campaigns the more selective reagent ion, $\mathrm{I}^{-}$, was found to sensitively detect $\mathrm{BrO}$ (Neuman et al., 2010). In addition, the capability of CIMS, using $\mathrm{I}^{-}$, to accurately and sensitively measure $\mathrm{BrO}$ was demonstrated in Liao et al. (2011a). Moving forward, CIMS observations of $\mathrm{BrO}$ with $\mathrm{I}^{-}$are preferred to $\mathrm{SF}_{6}^{-}$as the latter ion is more prone to interferences as it is more reactive (Huey et al., 1995). Consequently, conclusions drawn from the CIMS BrO observations in this study must be considered in the context of potential interferences, although the specific candidates for the interference are not known at this time.

\subsection{BrO measurement by DOAS}

The primary $\mathrm{BrO}$ measurement during the Summit campaign was a long path differential absorption spectrometer (LP DOAS). The techniques of the LP DOAS instrument were based on the work of Stutz and Platt (1997). The LP DOAS measured $\mathrm{BrO}$ over a path of either $2 \mathrm{~km}$ or $5 \mathrm{~km}(2007) / 4 \mathrm{~km}$ (2008). The optical paths were $1.5-3 \mathrm{~m}$ above the snow. The LP DOAS telescope was located at the edge of the clean air boundary in the south of the station and two reflectors were located $2 \mathrm{~km}$ and $5 \mathrm{~km}(2007) / 4 \mathrm{~km}$ (2008) to the South of the light source (Fig. 1). The details of $\mathrm{BrO}$ measurement by LP DOAS are provided by Stutz et al. (2011).

\subsection{Mercury measurement}

Tekran models 2537a/1130/1135 (Brooks et al., 2008) were used to measure gaseous elemental mercury (GEM), reactive gaseous mercury (RGM), also known as gaseous oxidized mercury (GOM), and fine particle mercury (FPM) via cold vapor atomic fluorescence. The details of the mercury measurements are described in the work of Brooks et al. (2011).

\subsection{Actinic Fluxes measurement}

Actinic Fluxes were measured by a Scanning Actinic Flux Spectrometer (SAFS) (Shetter and Muller, 1999) by University of Houston. The photolysis rate coefficients (J values) of atmospheric compounds were calculated based on the sum of downwelling and upwelling Actinic Fluxes. 


\subsection{Photochemical models}

A 0-Dimensional steady-state $\mathrm{HO}_{\mathrm{x}}-\mathrm{NO}_{\mathrm{x}}-\mathrm{CH}_{4}$ model is used to evaluate the $\mathrm{HO}_{\mathrm{x}}$ chemistry at Summit. The model is identical to that described in Sjostedt et al. (2007) and is denoted as the base model (BM). The BM involves 46 chemical reactions which include 8 photolysis reactions and is constrained by the measurements of photolysis rate coefficients ( $\mathrm{J}$ values) and the following gases: $\mathrm{H}_{2} \mathrm{O}, \mathrm{O}_{3}, \mathrm{CO}, \mathrm{CH}_{4}$, and $\mathrm{NO}$. The model only considered $\mathrm{CH}_{4}$ chemistry because previous studies by Chen et al. (2007) and Sjostedt et al. (2007) found that including nonmethane hydrocarbons (NMHC) decreased $\mathrm{OH}$ number densities and increased $\mathrm{HO}_{2}+\mathrm{RO}_{2}$ number densities less than $10 \%$ and that most of the $\mathrm{RO}_{2}$ is $\mathrm{CH}_{3} \mathrm{O}_{2}$ at Summit, Greenland. Typical levels of the dominant NMHC species ethane, propane, and butane are $1.0 \mathrm{ppbv}, 0.07 \mathrm{ppbv}$, and 0.04 ppbv, respectively. The NMHC measured in 2007 and 2008 were generally consistent with the measurements in 2003. The average ethane, propane and butane levels were $1.1 \mathrm{ppbv}, 0.14 \mathrm{ppbv}, 0.03 \mathrm{ppbv}$, respectively in spring 2007 and $0.9 \mathrm{ppbv}, 0.07 \mathrm{ppbv}, 0.02 \mathrm{ppbv}$ respectively in summer 2008. Because Summit Greenland is in the middle of Greenland Ice Sheet far away from biogenic and anthropogenic volatile organic carbons (VOCs) sources, we do not expect high levels of oxygenated VOCs reacting with $\mathrm{OH}$ at Summit, Greenland. Measurements of larger oxygenated VOCs at Summit, Greenland are needed to validate our assumption. The input data used to constrain the model were averaged to a $10 \mathrm{~min}$ basis. A spin-up time of $1000 \mathrm{~s}$ was used for model calculations of relatively long-lived species (e.g. $\mathrm{H}_{2} \mathrm{O}_{2}$ and $\mathrm{HCHO}$ ). The model predictions are compared to $\mathrm{OH}$ and $\mathrm{HO}_{2}+\mathrm{RO}_{2}$ measurements (assuming $\mathrm{RO}_{2}$ is primarily $\mathrm{CH}_{3} \mathrm{O}_{2}$ ). The rate constants are taken from the JPL compilation (Sander et al., 2006), and the J values are derived from the measured actinic fluxes (Shetter and Muller, 1999). Similar to the work of Sjostedt et al. (2007), the model can be run either constrained or unconstrained to HONO measurements. This allows evaluation of the impact of HONO on $\mathrm{HO}_{\mathrm{x}}$ levels and the radical budget. The model constrained to HONO observations is referred as BM_HONO.

To examine the impact of $\mathrm{BrO}$ on $\mathrm{HO}_{\mathrm{x}}$ levels, bromine reactions (see Table 2) were added to the $\mathrm{BM}$. The model incorporating the bromine chemistry is referred as BM_BrO. Reaction (R6) (in Table 2) acts as a source of $\mathrm{HO}_{\mathrm{x}}$. $\mathrm{HOBr}$ serves as a temporary reservoir of $\mathrm{HO}_{\mathrm{x}}$ and heterogeneous loss of $\mathrm{HOBr}$ is effectively a loss of $\mathrm{HO}_{\mathrm{x}}$. $\mathrm{HOBr}$ levels were assumed to be in steady-state and controlled by Reactions (R2), (R8) and (R9) (in Table 2). This assumption was valid because the photolysis lifetime of $\mathrm{HOBr}$ is relatively short ( $\sim 5 \mathrm{~min})$ at Summit Greenland in the daytime. The assumption was also found to reasonably predict the observed HOBr in Liao et al. (2011b). The box model is constrained by $\mathrm{BrO}$ measurements from CIMS and LP DOAS to illustrate the effect of two $\mathrm{BrO}$ datasets on $\mathrm{HO}_{\mathrm{x}}$ levels. The mass accommodation coefficient of $\mathrm{HOBr}$ is assumed to be 0.6 (Wachsmuth et al., 2002). This allowed predictions of $\mathrm{OH}$ and $\mathrm{HO}_{2}+\mathrm{RO}_{2}$ when $\mathrm{BrO}$ measurements were available. The model did not include the heterogeneous sinks of $\mathrm{BrONO}_{2}$ because the model is constrained to $\mathrm{BrO}$ measurements and $\mathrm{BrONO}_{2}$ does not directly impact the budget of $\mathrm{OH}$ and $\mathrm{HO}_{2}+\mathrm{RO}_{2}$. The impact of $\mathrm{BrONO}_{2}$ on daytime $\mathrm{NO}_{2}$ levels is also small due to the low $\mathrm{BrO}$ concentrations. Daytime $\mathrm{NO}_{2}$ levels increased $\sim 5 \%$ in 2007 and $\sim 2 \%$ in 2008 when the model considered bromine Reactions (R4) and (R5) in the Table 2. As the photochemical lifetime $(=\sim 2 \mathrm{~min})$ of $\mathrm{HO}_{2}$ is much shorter than the lifetime due to heterogeneous loss $(=\sim 150 \mathrm{~min})$ with a uptake coefficient of 0.1 (Mao et al., 2010), the model did not consider the heterogeneous loss of $\mathrm{HO}_{2}$.

One significant difference from the work of Sjostedt et al. (2007) is that observations of $\mathrm{CH}_{2} \mathrm{O}$ and $\mathrm{H}_{2} \mathrm{O}_{2}$ were not available. For this reason, the $\mathrm{BM}$ was used to predict $\mathrm{CH}_{2} \mathrm{O}$ and $\mathrm{H}_{2} \mathrm{O}_{2}$ levels. In order to test the ability of the model to calculate these species, predictions of $\mathrm{CH}_{2} \mathrm{O}$ and $\mathrm{H}_{2} \mathrm{O}_{2}$ using data from the 2004 Summit campaign were compared to observations. Both $\mathrm{CH}_{2} \mathrm{O}$ and $\mathrm{H}_{2} \mathrm{O}_{2}$ predictions are in reasonable agreement with the measurements $\left(\mathrm{CH}_{2} \mathrm{O}: R=0.68\right.$, mean $\mathrm{M} / \mathrm{O}=1.3 ; \mathrm{H}_{2} \mathrm{O}_{2}: R=0.72$, mean $\left.\mathrm{M} / \mathrm{O}=2.4\right)$, which suggests that the steady state model is viable for estimation of $\mathrm{CH}_{2} \mathrm{O}$ and $\mathrm{H}_{2} \mathrm{O}_{2}$ within about a factor of two. The impact of this relatively high uncertainty in mixing ratios of $\mathrm{CH}_{2} \mathrm{O}$ and $\mathrm{H}_{2} \mathrm{O}_{2}$ on predictions of $\mathrm{HO}_{\mathrm{x}}$ and its partitioning are discussed in Sect. 4.2.

\section{Results}

\section{1 $\mathrm{OH}$ and $\left(\mathrm{HO}_{2}+\mathrm{RO}_{2}\right)$ observations}

The time series of observations of $\mathrm{OH}, \mathrm{HO}_{2}+\mathrm{RO}_{2}, J\left(\mathrm{O}^{1} \mathrm{D}\right)$, $\mathrm{BrO}, \mathrm{NO}, \mathrm{HNO}_{3}, \mathrm{HONO}, \mathrm{O}_{3}, \mathrm{RGM}$, temperature, wind speeds and wind directions on a $10 \mathrm{~min}$ time base in spring 2007 and summer 2008 are shown in Fig. 2. The observations of $\mathrm{OH}$ and $\mathrm{HO}_{2}+\mathrm{RO}_{2}$ were filtered to exclude the periods when $\mathrm{NO}>50 \mathrm{pptv}$. High NO mixing ratios at Summit are almost always due to pollution plumes from the station power generator. High $\mathrm{NO}$ dramatically brought down the $\mathrm{HO}_{2}+\mathrm{RO}_{2}$ concentrations and raised the $\mathrm{OH}$ concentrations (Fig. 3). Similar phenomena were observed by previous works as well (e.g. Sjostedt et al., 2007; Bloss et al., 2007). The $\mathrm{HO}_{\mathrm{x}}$ instrument was shut down to save reagent gases at night (22:00-06:00 Western Greenland Standard Time (WGST)) when the $\mathrm{OH}$ concentrations decreased to near detection limit $\left(10^{5}\right.$ molec $\left.\mathrm{cm}^{-3}\right)$. The gaps in the data other than night time and high NO periods are due to instrument maintenance or malfunction.

Diurnal profiles of $\mathrm{OH}$ and $\mathrm{HO}_{2}+\mathrm{RO}_{2}$ largely followed the patterns of $J\left(\mathrm{O}^{1} \mathrm{D}\right)$ with a maximum at local noon, consistent with the behaviors of short-lived photochemically active species. Although $24 \mathrm{~h}$ of daylight are present in 
summer time at Summit, $J\left(\mathrm{O}^{1} \mathrm{D}\right)$ decreased by approximately a factor of 100 from noon to midnight. The maxima mid-day levels of $\mathrm{OH}$ and $\mathrm{HO}_{2}+\mathrm{RO}_{2}$ increased as temperature, $J\left(\mathrm{O}^{1} \mathrm{D}\right)$ and $\mathrm{O}_{3}$ increased, which were consistent with the previous finding that $\mathrm{O}^{1} \mathrm{D}$ reacting with $\mathrm{H}_{2} \mathrm{O}$ and snow emissions of $\mathrm{H}_{2} \mathrm{O}_{2}$ were the dominant $\mathrm{HO}_{\mathrm{x}}$ sources at Summit (Chen et al., 2007) (Mid-day is defined as 10:00-15:00 WGST). Overall, the maximum mid-day $\mathrm{OH}$ and $\mathrm{HO}_{2}+\mathrm{RO}_{2}$ concentrations increased during the measurement period in spring 2007 as the summer solstice was approached. There was no significant trend in the maximum mid-day $\mathrm{OH}$ and $\mathrm{HO}_{2}+\mathrm{RO}_{2}$ concentrations during summer 2008 (12 June 2008-8 July 2008) as the measurement period was centered about the solstice. The average mid-day $\mathrm{OH}$ and $\mathrm{HO}_{2}+\mathrm{RO}_{2}$ concentrations were higher in summer 2008 than that in spring 2007, likely a result of the higher radiative fluxes $\left(J_{\mathrm{O}_{3}}-2007 / J_{\mathrm{O}_{3}}-2008=1: 1.4\right)$ and dew points in summer time. The midday median ratio of $\mathrm{HO}_{2}+\mathrm{RO}_{2}$ to $\mathrm{OH}$ was 107:1 in spring 2007 and 102:1 in summer 2008 and the midday mean ratio of $\mathrm{HO}_{2}+\mathrm{RO}_{2}$ to $\mathrm{OH}$ was 109:1 with a standard deviation of 23 in spring 2007 and 108:1 with a standard deviation of 37 in summer 2008. The $\mathrm{HO}_{2}+\mathrm{RO}_{2}$ to $\mathrm{OH}$ ratios are comparable to other measurements performed in the lower troposphere in mid latitudes (Ren et al., 2008). The mid-day median and mean values of $\mathrm{OH}$ and $\mathrm{HO}_{2}+\mathrm{RO}_{2}$ observations, as well as $J\left(\mathrm{O}^{1} \mathrm{D}\right), J\left(\mathrm{NO}_{2}\right), \mathrm{NO}, \mathrm{HNO}_{3}, \mathrm{HONO}$, $\mathrm{O}_{3}, \mathrm{BrO}, \mathrm{RGM}$ and temperature in spring 2007 and summer 2008 are summarized in Table 3.

\section{2 $\mathrm{NO}, \mathrm{HNO}_{3}$ and $\mathrm{HONO}$ observations}

Diurnal profiles of NO and HONO were also observed at Summit. The average mid-day concentrations of NO and HONO were $\sim 12$ pptv and $\sim 6$ pptv, respectively. HONO levels were obtained from measurements of soluble nitrite $\left(\mathrm{NO}_{2}^{-}\right.$) from the mist chamber (Dibb et al., 2002). However, it should be noted that the derived HONO levels must be considered an upper limit to gas phase HONO as other species might also produce nitrite in solution. Following the simple $\mathrm{NO}_{\mathrm{x}}$ and HONO lifetime arguments in Chen et al. (2004); NO levels of 12 ppt and HONO levels of 6 ppt would seem to indicate that the soluble nitrite measurement includes species other than HONO. Due to the increase of the boundary layer height through the day, the diurnal profiles of NO had a local minimum at noon (Thomas et al., 2011). Elevated $\mathrm{HNO}_{3}$ was observed by mist chamber during the days when photochemically enhanced $\mathrm{NO}$ was observed. Higher $\mathrm{NO}, \mathrm{HNO}_{3}$ and HONO concentrations were observed in spring 2007 than in summer 2008.

\subsection{RGM and GEM observations}

Up to $\sim 250 \mathrm{pg} \mathrm{m}^{-3} \mathrm{RGM}$ were observed in the spring 2007 campaign. Clear diurnal profiles of RGM were observed when RGM was greater than $100 \mathrm{pg} \mathrm{m}^{-3}$. Because bromine atoms are one of the few established species that efficiently converts GEM into RGM (Ariya et al., 2002; Donohoue et al., 2006), elevated RGM peaks indicated that significant levels of BrO may be present. Higher RGM levels were observed in spring 2007 than in summer 2008, which suggests that the concentrations of $\mathrm{BrO}$ at Summit might be higher in spring 2007 than in summer 2008. High RGM appeared to coincide with photochemically enhanced $\mathrm{NO}$ and $\mathrm{HNO}_{3}$ in most cases. This is consistent with snow photochemistry activating bromine chemistry as described in Thomas et al. (2011).

\subsection{BrO observations}

$\mathrm{BrO}$ mixing ratios detected by the LP DOAS ranged from below detection limit to $5.5 \mathrm{pptv}$ with an average value of $1.6 \mathrm{pptv}$ in 2007 at Summit. BrO was also measured by CIMS in the later period of the 2007 campaign with a mean value of $1.7 \mathrm{pptv}$, ranging from below detection limit to 6.4 pptv. Lower BrO mixing ratios were observed by both LP DOAS $\left([\mathrm{BrO}]_{\text {mean }}=0.9 \mathrm{pptv}\right.$ for all data available $)$ and CIMS $\left([\mathrm{BrO}]_{\text {mean }}=1.5 \mathrm{pptv}\right.$ for all data available $)$ in summer 2008. $\mathrm{BrO}$ mixing ratios in 2008 generally ranged from below detection limit to 4 pptv and 5 pptv detected by LP DOAS and CIMS respectively. To be noted, the $\mathrm{BrO}$ concentrations at Summit were often near detection limits of both instruments. Diurnal patterns of $\mathrm{BrO}$ were observed in spring 2007 and the early part (10 June to 13 June) of summer 2008 by the CIMS with maximum concentrations in the daytime, which is consistent with $\mathrm{BrO}$ as a photochemically active product. No significant diurnal patterns of $\mathrm{BrO}$ were observed by the CIMS in the later period of summer 2008 as the daytime $\mathrm{BrO}$ levels were near the detection limit.

\section{Discussion}

\subsection{Model comparison}

\subsubsection{Base Model (BM)}

The predicted $\mathrm{OH}$ and $\mathrm{HO}_{2}+\mathrm{RO}_{2}$ from the $\mathrm{BM}$ are plotted against the observations in Fig. 4. Note that, the discrepancy between $\mathrm{HO}_{\mathrm{x}}$ observations and predictions increased at high wind speeds (WS $>8 \mathrm{~m} \mathrm{~s}^{-1}$ ) and were excluded from the comparisons. On average $26 \%$ of the $\mathrm{HO}_{\mathrm{x}}$ data were excluded and the correlation coefficients were improved ( $R$ increase 0.03 on average for BM_model) when $\mathrm{HO}_{\mathrm{x}}$ data were filtered at high wind speed conditions. Higher wind speed conditions did not clearly correspond to low photolysis rate or lower $\mathrm{NO}_{\mathrm{x}}$ levels. The correlation coefficient $(R)$ between photolysis rate and wind speeds were $<0.1$ in 2007 and 2008. The correlation coefficient $(R)$ between predicted $\mathrm{NO}_{2}$ and wind speeds were -0.35 in 2007 and -0.29 in 2008 . There is no clear systematic bias introduced when the $\mathrm{HO}_{\mathrm{x}}$ data were filtered at high wind speeds but this filter excluded the 
Table 2. Bromine reactions included in the $\mathrm{HO}_{\mathrm{x}}$ model.

\begin{tabular}{llll}
\hline $\begin{array}{l}\text { Reaction } \\
\text { number }\end{array}$ & Reactions & $\begin{array}{l}\text { Reaction rate coefficient } k \\
\left(\mathrm{~cm}^{3} \mathrm{molec}^{-1} \mathrm{~s}^{-1} \mathrm{or} \mathrm{s}^{-1}\right)\end{array}$ & $\begin{array}{l}k(T=250 \mathrm{~K}) \\
\left(\mathrm{cm}^{3} \mathrm{molec}^{-1} \mathrm{~s}^{-1} \mathrm{or} \mathrm{s}^{-1}\right)\end{array}$ \\
\hline 1 & $\mathrm{Br}+\mathrm{O}_{3} \rightarrow \mathrm{BrO}+\mathrm{O}_{2}$ & $1.7 \times 10^{-11} \exp (-800 / T)$ & $6.9 \times 10^{-13}$ \\
2 & $\mathrm{BrO}+\mathrm{HO}_{2} \rightarrow \mathrm{HOBr}+\mathrm{O}_{2}$ & $4.5 \times 10^{-12} \exp (460 / T)$ & $2.8 \times 10^{-11}$ \\
$3 \mathrm{a}$ & $\mathrm{BrO}+\mathrm{BrO} \rightarrow 2 \mathrm{Br}+\mathrm{O}_{2}$ & $2.4 \times 10^{-12} \exp (40 / T)$ & $2.8 \times 10^{-12}$ \\
$3 \mathrm{~b}$ & $\rightarrow \mathrm{Br}_{2}+\mathrm{O}_{2}$ & $2.8 \times 10^{-14} \exp (860 / T)$ & $8.7 \times 10^{-13}$ \\
4 & $\mathrm{BrO}+\mathrm{NO} \rightarrow \mathrm{Br}+\mathrm{NO}_{2}$ & $8.8 \times 10^{-12} \exp (260 / T)$ & $2.5 \times 10^{-11}$ \\
5 & $\mathrm{BrO}+\mathrm{NO}_{2}+\mathrm{M} \rightarrow \mathrm{BrONO}_{2}+\mathrm{M}$ & $k_{0}=5.2 \times 10^{-31} \exp (T / 300)^{-3.2}$ & $5.3 \times 10^{-12}$ \\
& & $k=6.9 \times 10^{-12} \exp (T / 300)^{-2.9}$ & \\
6 & $\mathrm{Br}+\mathrm{CH}_{2} \mathrm{O} \rightarrow \mathrm{HBr}+\mathrm{HCO}$ & $0.7 \times 10^{-11} \exp (-800 / T)$ & $6.9 \times 10^{-13}$ \\
7 & $\mathrm{BrO}+h v \rightarrow \mathrm{Br}+\mathrm{O}$ & $3 \times 10^{-3}-4 \times 10^{-3}($ at noon $)$ & \\
8 & $\mathrm{HOBr}+h v \rightarrow \mathrm{Br}+\mathrm{OH}$ & $\sim 1 \times 10^{-4}$ & \\
9 & Uptake of $\mathrm{HOBr}$ on heterogeneous surface & & \\
\hline
\end{tabular}
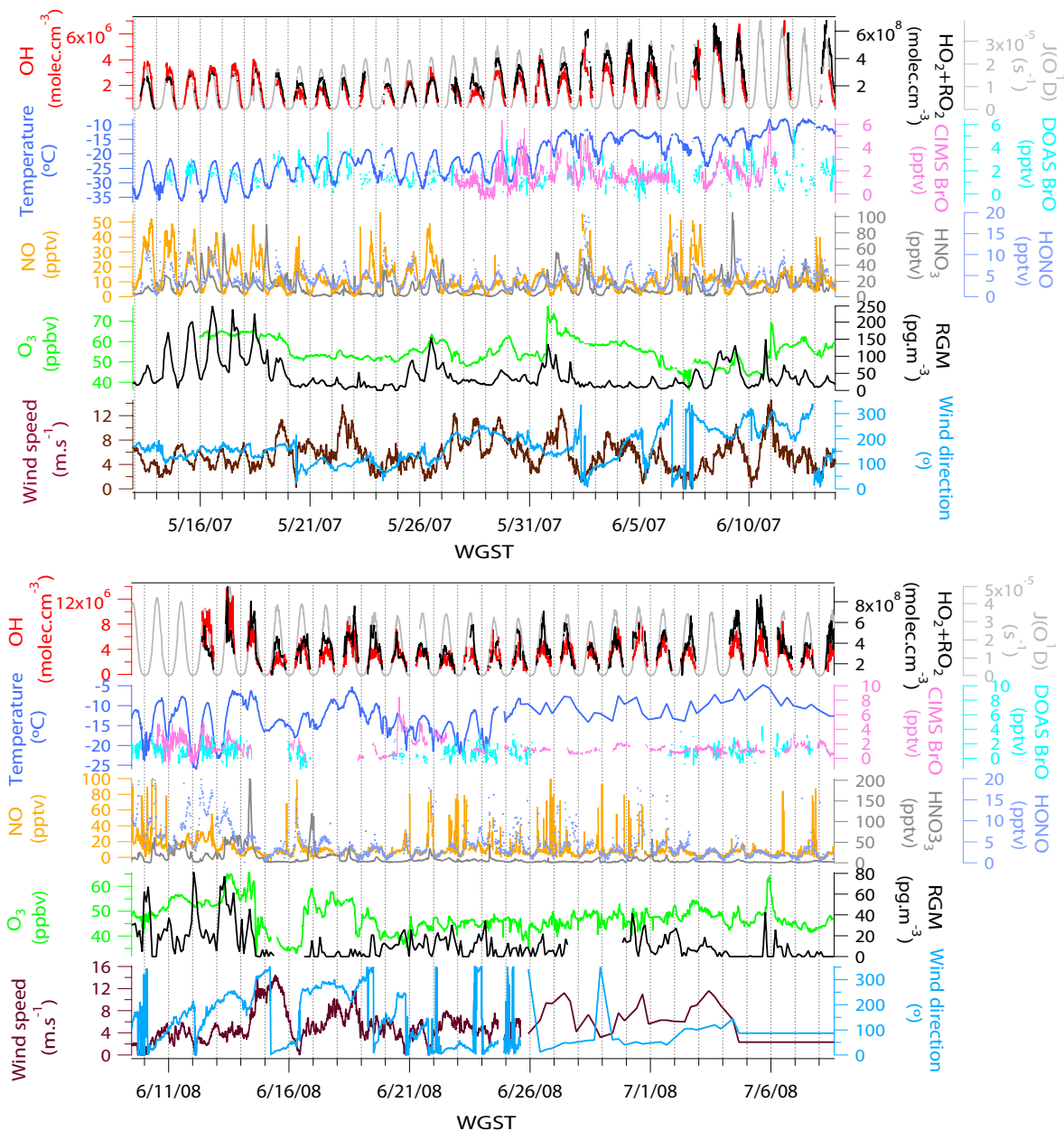

Fig. 2. Time series of measurements of $\mathrm{HO}_{2}+\mathrm{RO}_{2}, \mathrm{OH}, J\left(\mathrm{O}^{1} \mathrm{D}\right), \mathrm{BrO}$, temperature, $\mathrm{NO}, \mathrm{HNO}_{3}, \mathrm{HONO}, \mathrm{O}_{3}$, $\mathrm{RGM}$, wind speeds and directions on a 10 min time base in spring 2007 (top panel) and summer 2008 (bottom panel) Summit campaign. 
Table 3. Photochemical species concentrations and parameters in the mid-day (10:00-15:00 WGST) at Summit, Greenland in 2007-2008. (Note: $\mathrm{HO}_{\mathrm{x}}$ predictions are from the base model.)

\begin{tabular}{|c|c|c|c|c|}
\hline \multirow[t]{2}{*}{ Species } & \multicolumn{2}{|c|}{$\begin{array}{c}\text { Year } 2007 \\
\text { (13 May-13 June) }\end{array}$} & \multicolumn{2}{|c|}{$\begin{array}{c}\text { Year 2008 } \\
\text { (10 June-8 July) }\end{array}$} \\
\hline & Median & Average & Median & Average \\
\hline $\mathrm{OH}\left(10^{6} \mathrm{molec}^{-3}\right)$ & 3.0 & 3.1 & 4.1 & 4.6 \\
\hline $\mathrm{HO}_{2}+\mathrm{RO}_{2}\left(10^{8}\right.$ molec $\left.\mathrm{cm}^{-3}\right)$ & 2.7 & 3.3 & 4.2 & 4.4 \\
\hline OH pred $\left(10^{6}\right.$ molec $\left.\mathrm{cm}^{-3}\right)$ & 2.4 & 2.6 & 3.7 & 3.8 \\
\hline $\mathrm{HO}_{2}+\mathrm{RO}_{2}$ pred $\left(10^{8}\right.$ molec $\left.\mathrm{cm}^{-3}\right)$ & 3.0 & 3.2 & 4.6 & 4.6 \\
\hline NO (pptv) & 12.8 & 17.2 & 8.6 & 11.4 \\
\hline $\mathrm{O}_{3}$ (ppbv) & 54.6 & 55.3 & 47.3 & 47.9 \\
\hline $\mathrm{BrO}_{\text {LPDOAS }}$ (pptv) & 1.5 & 1.6 & 1.0 & 0.9 \\
\hline $\mathrm{BrO}_{\text {CIMS }}(\mathrm{pptv})$ & 1.8 & 2.0 & 1.5 & 2.0 \\
\hline $\operatorname{RGM}\left(\operatorname{pg~m}^{-3}\right)$ & 41.8 & 64.8 & 7.2 & 9.6 \\
\hline $\mathrm{HNO}_{3}$ (pptv) & 12.9 & 15.9 & 5.5 & 11.5 \\
\hline HONO (pptv) & 6.5 & 7.3 & 4.7 & 5.8 \\
\hline$J\left(\mathrm{O}^{1} \mathrm{D}\right)\left(10^{-5} \mathrm{~s}^{-1}\right)$ & 2.2 & 2.3 & 3.3 & 3.3 \\
\hline$J \mathrm{NO}_{2}\left(\mathrm{~s}^{-1}\right)$ & 0.014 & 0.014 & 0.016 & 0.016 \\
\hline Temperature $\left({ }^{\circ} \mathrm{C}\right)$ & -19.5 & -18.2 & -10.7 & -10.6 \\
\hline
\end{tabular}

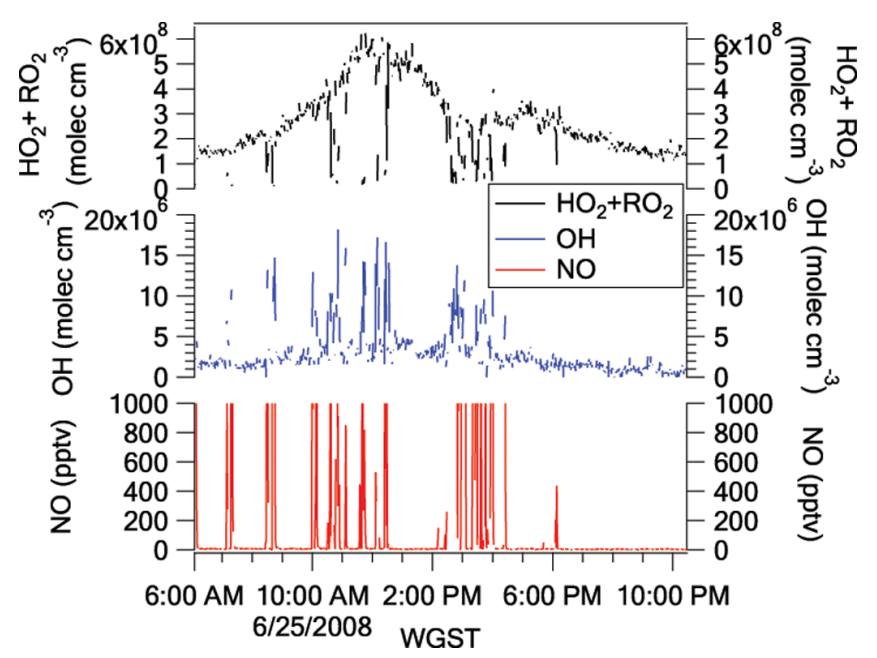

Fig. 3. An example of elevated $\mathrm{OH}$ and depleted $\mathrm{HO}_{2}+\mathrm{RO}_{2}$ at high NO conditions. The spikes in $\mathrm{NO}$ and the responses in $\mathrm{OH}$ and $\mathrm{HO}_{2}+\mathrm{RO}_{2}$ are due to the measurement cite being impacted by the plume of the generator.

most scattered points. It is possible that the uncertainty in the CIMS calibration increases at high wind speeds $\left(>8 \mathrm{~m} \mathrm{~s}^{-1}\right)$ due to turbulent flow in the inlet as suggested in Sjostedt et al. (2007). Overall, the observed and predicted $\mathrm{OH}$ and $\mathrm{HO}_{2}+\mathrm{RO}_{2}$ from the BM were well correlated $\left(\mathrm{HO}_{2}+\mathrm{RO}_{2}\right.$ : $R=0.90$, OH: $R=0.83$ in $2007 ; \mathrm{HO}_{2}+\mathrm{RO}_{2}: R=0.79$, $\mathrm{OH}: R=0.76$ in 2008). The $\mathrm{BM}$ well predicted the magnitude of $\mathrm{HO}_{2}+\mathrm{RO}_{2}$ and under predicted $\mathrm{OH}$, especially in summer $2008\left(\mathrm{HO}_{2}+\mathrm{RO}_{2}\right.$ : slope $=0.87, \mathrm{OH}$ : slope $=0.72 \mathrm{in}$
2007; $\mathrm{HO}_{2}+\mathrm{RO}_{2}$ : slope $=0.96, \mathrm{OH}$ : slope $=0.54$ in 2008). The slopes were given by equally weighted bivariate regressions. The agreement between the predicted and observed $\mathrm{HO}_{2}+\mathrm{RO}_{2}$ (which is dominated by $\mathrm{HO}_{2}$ ) indicates that we have a good understanding of the major sources and sinks of $\mathrm{HO}_{2}$ which dominates the $\mathrm{HO}_{\mathrm{x}}$ family. However, our understanding of the $\mathrm{OH}$ sources and sinks is clearly lacking especially during periods of elevated RGM (see Sect. 4.4). The model predicted an average midday $\mathrm{HO}_{2}+\mathrm{RO}_{2}$ to $\mathrm{OH}$ ratio of 121:1 in 2007 and 125:1 in 2008, consistent with the values predicted by Chen et al. (2007) using input data from the summit 2003 campaign. The observed average midday $\mathrm{HO}_{2}+\mathrm{RO}_{2}$ to $\mathrm{OH}$ ratios were 109:1 in 2007 and 108:1 in 2008. The predicted and observed $\mathrm{HO}_{2}+\mathrm{RO}_{2}$ to $\mathrm{OH}$ ratios indicate that a mechanism rolling $\mathrm{HO}_{2}$ back to $\mathrm{OH}$ may be missing, with halogen chemistry a likely prospect.

\subsubsection{Base Model constrained to HONO measurements (BM_HONO)}

The correlation coefficients and slopes between predictions from the BM_HONO and observations are shown in Fig. 5 $\left(\mathrm{HO}_{2}+\mathrm{RO}_{2}: R=0.84\right.$, slope $=0.90$ in 2007 and $R=0.79$, slope $=1.09$ in 2008; OH: $R=0.78$, slope $=0.92$ in 2007 and $R=0.78$, slope $=0.72$ in 2008). The slopes were given by equally weighted bivariate regressions. The correlation coefficient $(R)$ between predicted and observed $\mathrm{HO}_{\mathrm{x}}$ did not improve when the model included HONO source. In 2007, the average modeled to observed $(\mathrm{M} / \mathrm{O})$ ratios of $\mathrm{HO}_{2}+\mathrm{RO}_{2}$ and $\mathrm{OH}$ were 0.87 and 0.84 from the $\mathrm{BM}$, and were 1.18 and 1.25 from the BM_HONO. In 2008, the average M/O ratios 

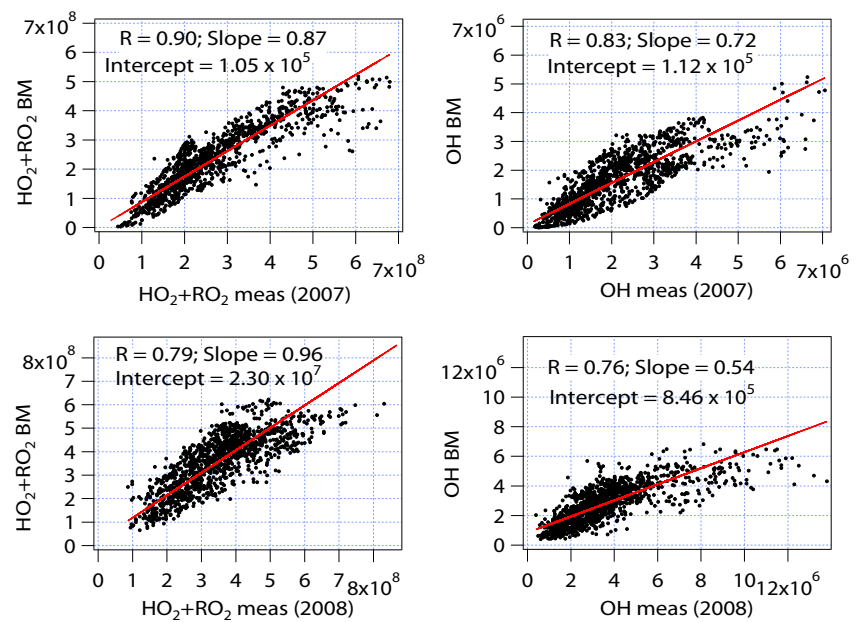

Fig. 4. $\mathrm{HO}_{2}+\mathrm{RO}_{2}$ and $\mathrm{OH}$ predictions from the base mode (BM) plotted versus the observations in 2007 and 2008. The data are average on a $10 \mathrm{~min}$ time base. The correlation coefficient $(R)$ and the slope and intercept from an equally weighted bivariate regression (red line) for each panel are also denoted in the figure. The units of $\mathrm{OH}$ and $\mathrm{HO}_{2}+\mathrm{RO}_{2}$ concentrations are molec $\mathrm{cm}^{-3}$.
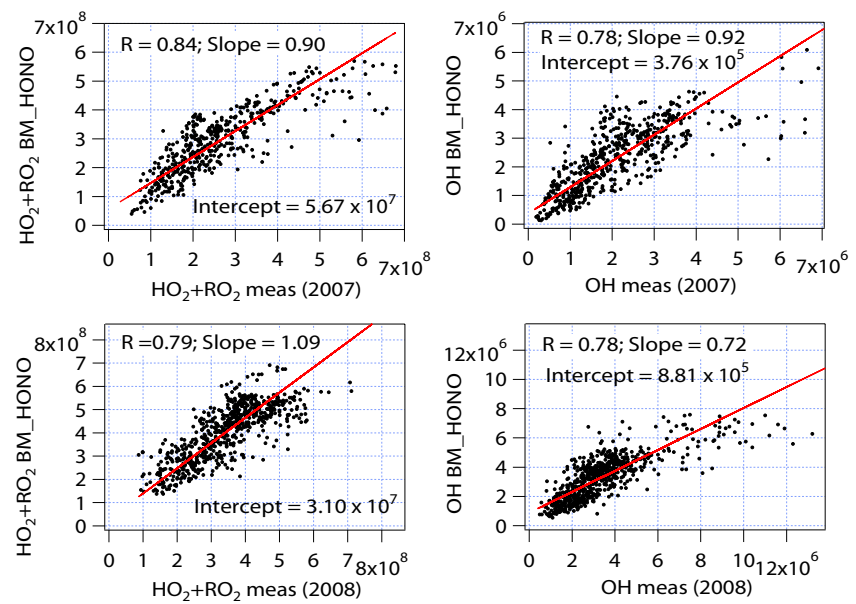

Fig. 5. $\mathrm{HO}_{2}+\mathrm{RO}_{2}$ and $\mathrm{OH}$ predictions from the base model constrained to HONO measurements (BM_HONO) plotted versus the observations in 2007 and 2008. The data are average on a $10 \mathrm{~min}$ time base. The correlation coefficient $(R)$ and the slope and intercept from an equally weighted bivariate regression (red line) for each panel are also denoted in the figure. The units of $\mathrm{OH}$ and $\mathrm{HO}_{2}+\mathrm{RO}_{2}$ concentrations are molec $\mathrm{cm}^{-3}$.

of $\mathrm{HO}_{2}+\mathrm{RO}_{2}$ and $\mathrm{OH}$ were 1.06 and 0.87 from the $\mathrm{BM}$, and were 1.22 and 1.05 from the BM_HONO. The predictions of both $\mathrm{OH}$ and $\mathrm{HO}_{2}+\mathrm{RO}_{2}$ from the BM_HONO were higher than that from the $\mathrm{BM}$ as this adds in a $\mathrm{HO}_{\mathrm{x}}$ source. However, the ratio of $\mathrm{HO}_{2}+\mathrm{RO}_{2}$ to $\mathrm{OH}$ changed by less than $10 \%$ on average. As the $\mathrm{HO}_{\mathrm{x}}$ predictions from the $\mathrm{BM}$ had more data points, the correlation between predicted and observed $\mathrm{HO}_{\mathrm{x}}$ did not improve when HONO was included in the model, and the observed HONO is likely to have interferences (Stutz et al., 2010; Sjostedt et al., 2007), the BM is preferred for comparison to $\mathrm{HO}_{\mathrm{x}}$ observations in this work.

\subsubsection{Model incorporating halogen chemistry (BM_BrO)}

To investigate the impact of $\mathrm{BrO}$ on $\mathrm{HO}_{\mathrm{x}}$, predicted $\mathrm{OH}$ and $\mathrm{HO}_{2}+\mathrm{RO}_{2}$ from the BM_BrO unconstrained by $\mathrm{HONO}$ measurements and constrained by $\mathrm{BrO}$ measurements from the CIMS (BM_BrO ${ }_{\text {CIMS }}$ ) and LP DOAS (BM_BrOLPDOAS) in 2007 and 2008 are also plotted against the observations (Fig. 6). Overall, the correlation coefficients between the observed and predicted $\mathrm{OH}$ and $\mathrm{HO}_{2}+\mathrm{RO}_{2}$ were slightly improved (increased 0.03 except $\mathrm{HO}_{2}+\mathrm{RO}_{2}$ in 2007) by incorporation of bromine chemistry with the $\mathrm{BrO}$ constrained to the CIMS observations. When the model included bromine chemistry and was constrained to CIMS $\mathrm{BrO}$, the intercept increased from $1.12 \times 10^{5}$ molec $\mathrm{cm}^{-3}$ to $1.65 \times 10^{5}$ molec $\mathrm{cm}^{-3}$ and the slope increased from 0.72 to 0.78 in 2007 and the intercept increased from $8.64 \times 10^{5}$ molec cm ${ }^{-3}$ to $9.23 \times 10^{5}$ molec $\mathrm{cm}^{-3}$ and the slope increased from 0.54 to 0.56 in 2008 for $\mathrm{OH}$. When the model included bromine chemistry and was constrained to LPDOAS $\mathrm{BrO}$, the intercepts increased from $1.12 \times 10^{5}$ molec cm ${ }^{-3}$ to $3.20 \times 10^{5}$ molec $\mathrm{cm}^{-3}$ and the slope remained the same in 2007 and the intercept increased from $8.46 \times 10^{5}$ molec $\mathrm{cm}^{-3}$ to $1.15 \times 10^{6}$ molec cm $^{-3}$ and the slope slightly decreased from 0.54 to 0.50 in 2008 for $\mathrm{OH}$. To give a general idea of the difference between predicted $\mathrm{OH}$ and $\mathrm{HO}_{2}+\mathrm{RO}_{2}$ from the $\mathrm{BM}$ and $\mathrm{BM} \_\mathrm{BrO}$, the average ratios of $\mathrm{OH}$ and $\mathrm{HO}_{2}+\mathrm{RO}_{2}$ from both models as well as the slopes and intercepts from linear equally weighted bivariate regression are also provided. Predicted $\mathrm{OH}$ increased $12 \%\left([\mathrm{OH}]_{\text {pred_BrO_CIMS }} /[\mathrm{OH}]_{\text {pred }}\right)_{\text {avg }}$ in 2007 and $10 \%$ in 2008, and predicted $\mathrm{HO}_{2}+\mathrm{RO}_{2}$ decreased $10 \%$ in 2007 and $8 \%$ in 2008 on average when the BM_BrO was constrained to CIMS BrO. Predicted $\mathrm{OH}$ increased $10 \%$ in 2007 and $4 \%$ in 2008, and predicted $\mathrm{HO}_{2}+\mathrm{RO}_{2}$ decreased $8 \%$ in 2007 and $3 \%$ in 2008 on average when the BM_BrO was constrained to LP DOAS BrO. These results indicate that $\mathrm{BrO}$ impacted the concentrations of $\mathrm{OH}$ and $\mathrm{HO}_{2}+\mathrm{RO}_{2}$ at Summit, although all of the enhancement in observed $\mathrm{OH}$ relative to model predictions cannot be explained by the influence of $\mathrm{BrO}$.

\subsubsection{Impact of $\mathrm{H}_{2} \mathrm{O}_{2}$ and $\mathrm{CH}_{2} \mathrm{O}$}

Because $\mathrm{CH}_{2} \mathrm{O}$ and $\mathrm{H}_{2} \mathrm{O}_{2}$ were not observed, they had to be predicted with the photochemical model which may lead to under estimation of them as they are emitted to the atmosphere from the snowpack (Hutterli et al., 1999, 2001). Under estimation of $\mathrm{CH}_{2} \mathrm{O}$ and $\mathrm{H}_{2} \mathrm{O}_{2}$ results in under prediction of $\mathrm{OH}$ and $\mathrm{HO}_{2}+\mathrm{RO}_{2}$, but does not significantly impact the ratios of $\mathrm{OH} / \mathrm{HO}_{2}+\mathrm{RO}_{2}$. For example, a $30 \%$ increase in 

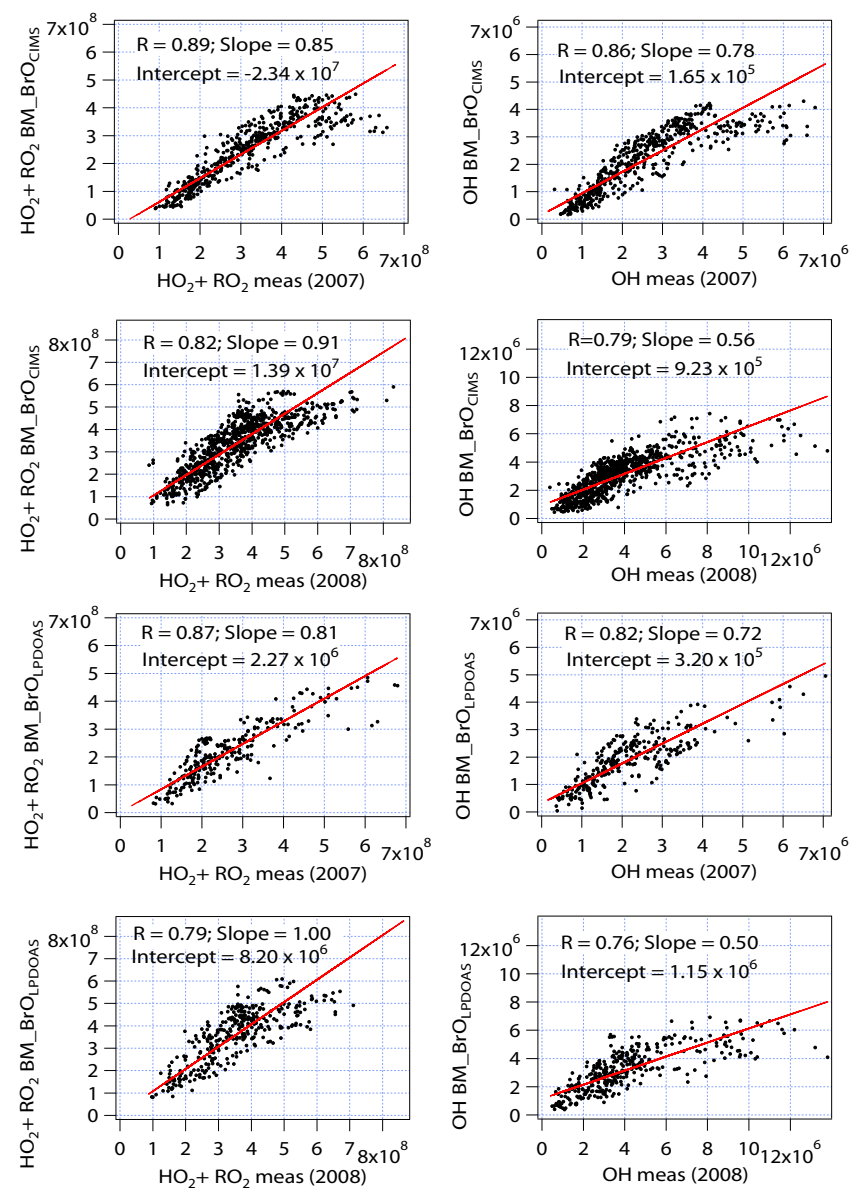

Fig. 6. $\mathrm{HO}_{2}+\mathrm{RO}_{2}$ and $\mathrm{OH}$ predictions from the base model incorporating bromine chemistry constrained by $\mathrm{BrO}$ measurements by CIMS (BM_BrO ${ }_{\text {CIMS }}$ ) and LPDOAS (BM_BrOLPDOAS $)$ plotted versus the observations in 2007 and 2008. The data are averaged on a $10 \mathrm{~min}$ time base. The correlation coefficient $(R)$ and the slope and intercept from an equally weighted bivariate regression (red line) for each panel are also denoted in the figure. The units of $\mathrm{OH}$ and $\mathrm{HO}_{2}+\mathrm{RO}_{2}$ concentrations are molec $\mathrm{cm}^{-3}$.

the model production rate of $\mathrm{H}_{2} \mathrm{O}_{2}$ or $\mathrm{CH}_{2} \mathrm{O}$ would increase $\mathrm{HO}_{\mathrm{x}}$ levels by $\sim 5 \%$ and $\sim 10 \%$ but would impact the ratio of $\mathrm{OH}$ to $\mathrm{RO}_{2}$ by less than $2 \%$. According to the study of $\mathrm{HO}_{\mathrm{x}}$ at Summit in 2003 by Chen et al. (2007), $\mathrm{H}_{2} \mathrm{O}_{2}$ is the largest snow emitted $\mathrm{HO}_{\mathrm{x}}$ sources at Summit, contributing to $37 \%$ of the net $\mathrm{HO}_{\mathrm{x}}$ sources compared to only $3 \%$ from $\mathrm{CH}_{2} \mathrm{O}$. As snow emissions of $\mathrm{H}_{2} \mathrm{O}_{2}$ increase with temperature (Chen et al., 2007), the warmer temperature in summer 2008 may have contributed to the lower correlation between predicted and observed $\mathrm{HO}_{\mathrm{x}}$ in that year. For this reason, temperature dependent snow emissions of $\mathrm{H}_{2} \mathrm{O}_{2}$, based on net snow-air exchange rate shown as the following equation, were added to the $\mathrm{BM}$.

$d\left[\mathrm{H}_{2} \mathrm{O}_{2}\right] / d t=A \times \exp \left(B /\right.$ Temperature $\left._{\text {snow }}\right)$

$-\mathrm{C} \times\left[\mathrm{H}_{2} \mathrm{O}_{2}\right]\left(\right.$ molec $\mathrm{cm}^{-3} \mathrm{~s}^{-1}$ or ppbv hr $\left.{ }^{-1}\right)$
$A, B$ and $C$ are adjustable constants. Temperature is assumed to be ambient temperature instead of snow temperature. $\left[\mathrm{H}_{2} \mathrm{O}_{2}\right]$ represents ambient $\mathrm{H}_{2} \mathrm{O}_{2}$ concentration (Chen et al., 2007). No significant improvement of the correlation was found between predicted and observed $\mathrm{HO}_{\mathrm{x}}$. However, as observations of $\mathrm{H}_{2} \mathrm{O}_{2}$ and $\mathrm{CH}_{2} \mathrm{O}$ were not carried out in 2007 or 2008 , enhanced snow photochemistry producing these and potentially other radical precursors in 2008 cannot be ruled out.

\subsection{Average comparison}

Figure 7 shows the average diurnal profiles of hourly $\mathrm{OH}$ and $\mathrm{HO}_{2}+\mathrm{RO}_{2}$ concentrations from observations and predictions from the $\mathrm{BM}$ and the $\mathrm{BM} \mathrm{BrO}$ constrained to CIMS measurements in 2007 and 2008. The error bars of the observations are the overall uncertainties including the measurement uncertainties and ambient fluctuations. The error bars of the predictions are the propagated uncertainties from the model inputs uncertainties and variations. The $\mathrm{BM}$ simulated the concentrations of $\mathrm{OH}$ and $\mathrm{HO}_{2}+\mathrm{RO}_{2}$ within the combined uncertainties, except for the $\mathrm{OH}$ concentrations in the late afternoons in summer 2008. This confirms that the $\mathrm{BM}$ captures the dominant $\mathrm{HO}_{\mathrm{x}}$ sources and sinks. The BM also under predicts the $\mathrm{OH}$ concentrations in both 2007 and 2008. The midday median modeled to observed (M/O) ratio of $\mathrm{OH}$ was 0.88 and 0.87 in 2007 and 2008, and the midday median $\mathrm{M} / \mathrm{O}$ ratio of $\mathrm{HO}_{2}+\mathrm{RO}_{2}$ was 0.97 and 1.08 in 2007 and 2008. A low M/O ratio of $\mathrm{OH}$ was also reported in Sjostedt et al. (2007). The average hourly $\mathrm{HO}_{2}+\mathrm{RO}_{2}$ and $\mathrm{OH}$ predictions from the $\mathrm{BM} \_\mathrm{BrO}$ constrained to CIMS $\mathrm{BrO}$ measurements in 2007 slightly over estimated their concentrations due to the absence of CIMS BrO measurements in the early period of the 2007 campaign and the increase in $\mathrm{HO}_{\mathrm{x}}$ levels in the late period of the 2007 campaign relative to the early period. The $\mathrm{OH}$ concentrations predicted from BM_BrO were higher compared to the results from the $\mathrm{BM}$, and the average hourly predicted $\mathrm{HO}_{2}+\mathrm{RO}_{2}$ concentrations slightly decreased when $\mathrm{BM}$ incorporated bromine chemistry in 2008. The model including bromine chemistry brought the predictions both of $\mathrm{OH}$ and $\mathrm{HO}_{2}+\mathrm{RO}_{2}$ closer to the observations in 2008. The impact of bromine chemistry on $\mathrm{HO}_{2}+\mathrm{RO}_{2}$ concentrations was smaller than on $\mathrm{OH}$ concentrations. The box model consistently under predicts the $\mathrm{OH}$ concentrations in the later afternoons, which indicates that box model underestimates the sources of $\mathrm{OH}$ as the radiation flux and boundary layer height decrease or there may be a change in the sinks or cycling. A similar behavior was observed by Sjostedt et al. (2007). Snow emitted compounds with higher concentrations or steeper vertical gradients in the later afternoon not included in the photochemical box model may contribute to the under predictions of $\mathrm{OH}$ and impact the photochemistry at Summit in the later afternoon. 

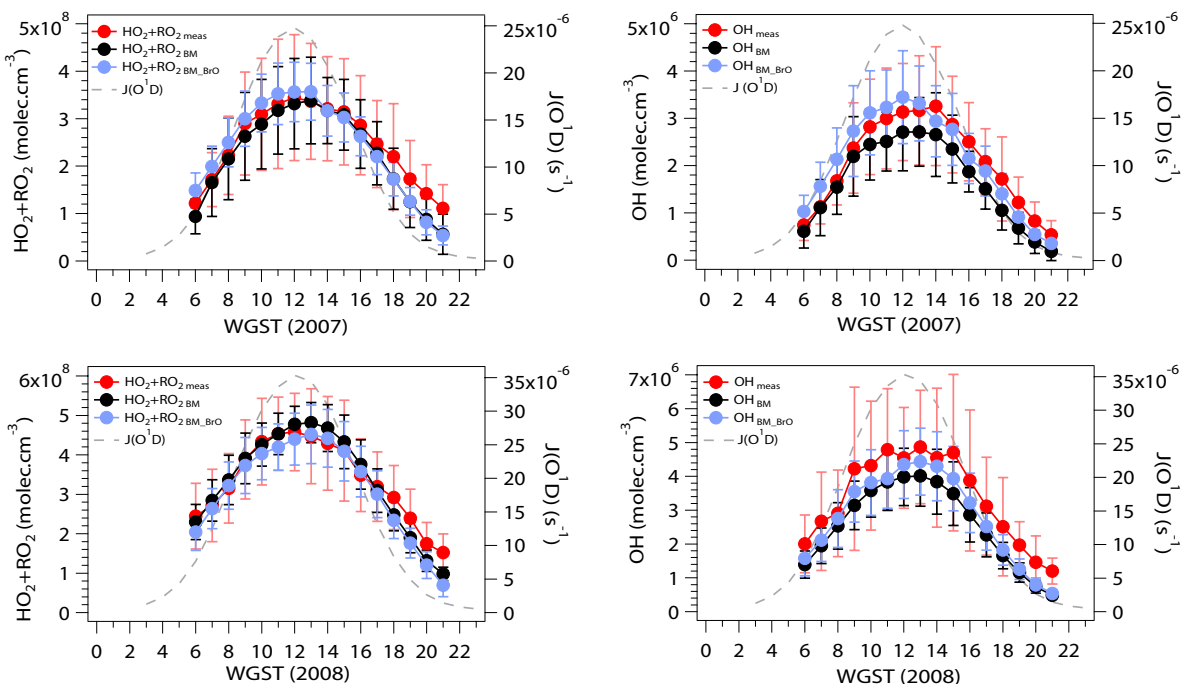

Fig. 7. The average diurnal profiles of hourly $\mathrm{OH}$ and $\mathrm{HO}_{2}+\mathrm{RO}_{2}$ observations (red dots and line) and predictions from the $\mathrm{BM}$ (black dots and line) and BM_BrO ${ }_{\mathrm{CIMS}}$ (blue dots and line), and diurnal profile of $J\left(\mathrm{O}^{1} \mathrm{D}\right)$ (gray dash line) in spring 2007 and summer 2008 . The error bars (red) of the observations are the overall uncertainties including the measurement uncertainties and ambient fluctuations. The error bars (gray and blue) of the predictions are the propagated uncertainties from the model input uncertainties and variations.
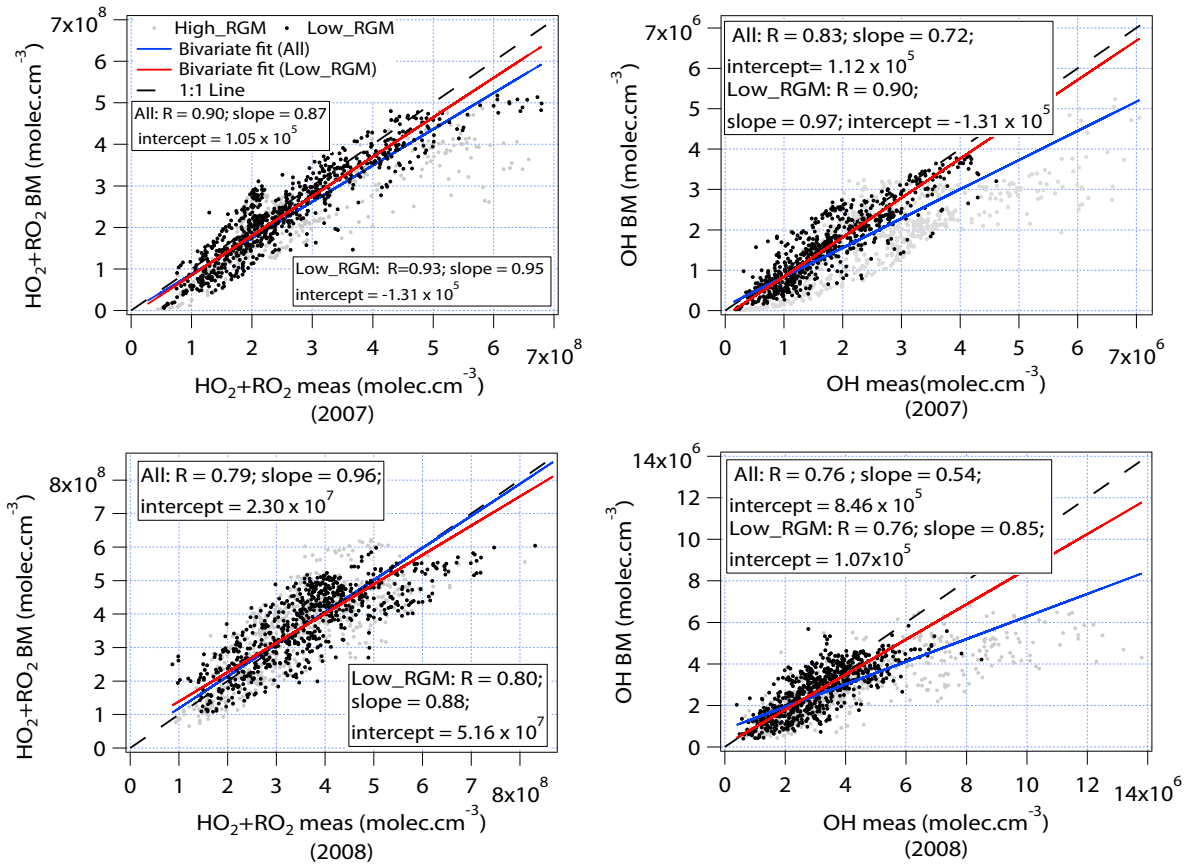

Fig. 8. The correlation plots of observed and predicted $\mathrm{OH}$ and $\mathrm{HO}_{2}+\mathrm{RO}_{2}$ from the $\mathrm{BM}$ at low $\mathrm{RGM}$ conditions (black dots) and at high RGM conditions (gray dots) in 2007 and 2008. "All” represents the total data including low RGM and high RGM conditions. Equally weighted bivariate regressions are applied to all the data (blue line) and the data at low RGM conditions (red line), respectively. The relevant correlation coefficients, slopes, and intercepts are provided in the figure.

\subsection{Enhanced OH and RGM}

Due to the limitations of $\mathrm{BrO}$ measurements discussed earlier, observations of RGM were also investigated as a proxy for bromine and potentially other chemistry. The correlations between the $\mathrm{BM}$ predictions and observations of $\mathrm{HO}_{\mathrm{x}}$ were examined for enhanced RGM levels (gray dots in Fig. 8) and low RGM levels (black dots in Fig. 8). RGM levels were considered to be enhanced when they were above average levels 

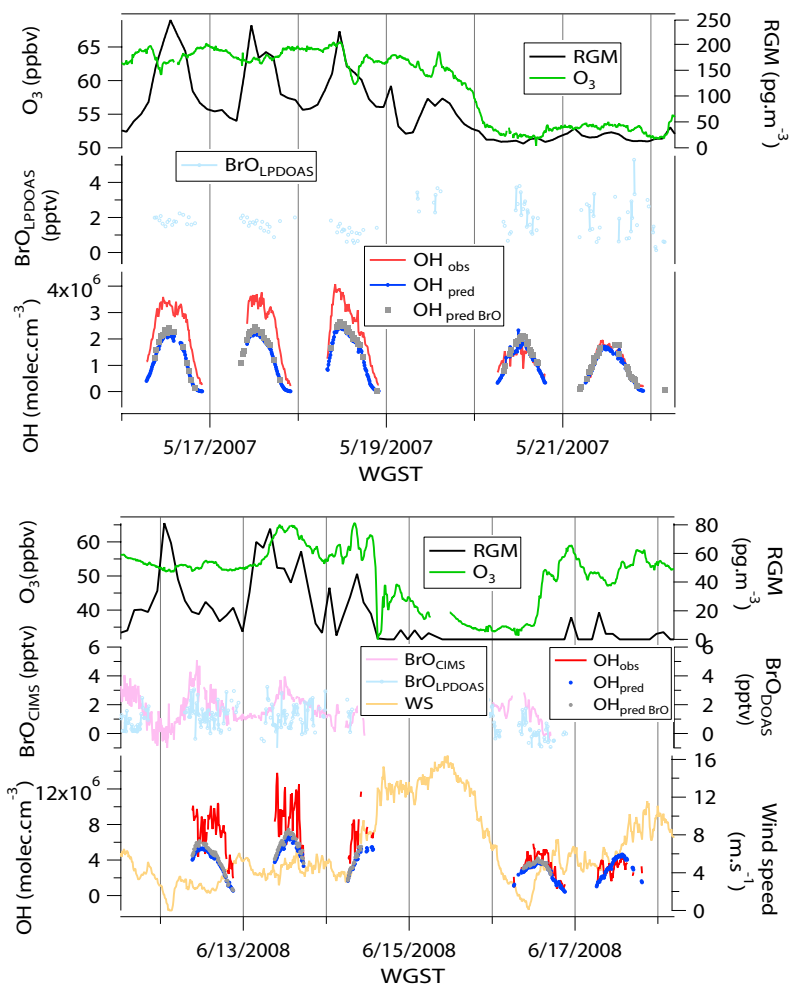

Fig. 9. (a): Observations of $\mathrm{RGM}, \mathrm{O}_{3}, \mathrm{BrO}$ by DOAS and $\mathrm{OH}$, and predictions of $\mathrm{OH}$ from the BM and BM_BrO when enhanced RGM were observed in 2007 (16 May-21 May 2007); (b): The observations of $\mathrm{RGM}, \mathrm{O}_{3}, \mathrm{OH}$, wind speeds, BrO by CIMS and DOAS, and the predictions of $\mathrm{OH}$ from the BM and BM_BrO when enhanced RGM were observed in 2008 (11 June-17 June 2008).

for each of the field seasons and season means were 45 and $11 \mathrm{pg} \mathrm{m}^{-3}$ in 2007 and 2008, respectively.

When high RGM periods were excluded, the slope between the predicted and observed $\mathrm{OH}$ significantly increased: the slope of $\mathrm{OH}$ increased from 0.72 to 0.97 in 2007 and increased from 0.54 to 0.85 in 2008 . The correlation between the predicted and observed $\mathrm{OH}$ and $\mathrm{HO}_{2}+\mathrm{RO}_{2}$ in 2007 also slightly improved: the correlation coefficient increased from 0.83 to 0.90 for $\mathrm{OH}$ and increased from 0.90 to 0.93 for $\mathrm{HO}_{2}+\mathrm{RO}_{2}$. For the 2008 data the correlation was essentially unchanged when high RGM periods were excluded. These results indicate that $\mathrm{OH}$ levels are enhanced above predictions when RGM is enhanced. This is consistent with other chemistry (e.g. other halogens) coincident with the $\mathrm{Br}$ chemistry that leads to elevated RGM impacting the production of $\mathrm{OH}$ from $\mathrm{HO}_{2}$ and $\mathrm{RO}_{2}$.

\subsection{Case study with high RGM}

The concentrations of $\mathrm{OH}, \mathrm{O}_{3}, \mathrm{RGM}$, and $\mathrm{BrO}$ during two periods (16 May-21 May 2007; 12 June-17 June 2008) are shown in Fig. 9. The BM clearly under predicted $\mathrm{OH}$ during 16 May-18 May 2007 (Fig. 9a). Clear diurnal profiles of RGM were present during the same period, with a maximum concentration of near $250 \mathrm{pg} \mathrm{m}^{-3}$. The RGM peaks indicate that certain levels of $\mathrm{Br}$ and $\mathrm{BrO}$ may be present during these periods. Small $\mathrm{O}_{3}$ concentration drops also occurred with the RGM peaks, possibly a result of bromine catalyzed $\mathrm{O}_{3}$ depletion. Up to 5 pptv of $\mathrm{BrO}$ were observed by LP DOAS and no CIMS BrO measurements were available during this time. $\mathrm{OH}$ predictions from BM_BrO constrained by LP DOAS BrO measurements cannot account for the enhanced $\mathrm{OH}$ observed.

Figure $9 \mathrm{~b}$ shows the early period of 2008 campaign including three days (12 June-14 June 2008) with obvious under prediction of $\mathrm{OH}$. The RGM peaks during this period were the highest values in 2008 campaign with a maximum of $\sim 80 \mathrm{pg} \mathrm{m}^{-3}$. During this period, up to $4-5 \mathrm{pptv}$ of $\mathrm{BrO}$ were observed by CIMS, and up to $\sim 3$ pptv of $\mathrm{BrO}$ were observed by LP DOAS. The BrO levels were near the detection limits of the LP DOAS and CIMS instruments. The gaps of $\mathrm{BrO}$ and $\mathrm{HO}_{\mathrm{x}}$ measurements during 12 June-14 June 2008 were due to the extremely high wind speeds $\left(>12 \mathrm{~m} \mathrm{~s}^{-1}\right)$. The $\mathrm{OH}$ predictions from BM_BrO constrained by CIMS BrO measurements are also shown in Fig. 9b. These levels of $\mathrm{BrO}$ were not large enough to explain the under prediction of $\mathrm{OH}$. The $\mathrm{BrO}$ concentrations during 12 June-14 June 2008 only contribute $\sim 10 \%$ to the $\mathrm{OH}$ production rate.

\section{Conclusions}

The median midday values of $\mathrm{HO}_{2}+\mathrm{RO}_{2}$ and $\mathrm{OH}$ concentrations observed by CIMS were $2.7 \times 10^{8}$ molec $^{-3}$ and $3.0 \times 10^{6} \mathrm{molec} \mathrm{cm}^{-3}$ in spring 2007, and $4.2 \times 10^{8}$ molec cm ${ }^{-3}$ and $4.1 \times 10^{6}$ molec cm $^{-3}$ in summer 2008 at Summit. The BM was reasonably accurate for $\mathrm{HO}_{2}+\mathrm{RO}_{2} \quad(R=0.90$, slope $=0.87$ in $2007 ; R=0.79$, slope $=0.96$ in 2008) but under predicted $\mathrm{OH}(R=0.83$, slope $=0.72$ in 2007; $R=0.76$, slope $=0.54$ in 2008). This confirmed our understanding of the dominant $\mathrm{HO}_{\mathrm{x}}$ sources and sinks in this environment and that there may be mechanisms perturbing $\mathrm{HO}_{\mathrm{x}}$ cycling and enhancing $\mathrm{OH}$ above the snow pack. Inclusion of HONO source in the model did not impact the correlation between predictions and observations of $\mathrm{HO}_{\mathrm{x}}$ significantly and did not improve the ratio of $\mathrm{OH}$ to $\mathrm{HO}_{2}+\mathrm{RO}_{2}$. BrO levels detected by CIMS and LP DOAS generally ranged from below detection limits to $\sim 6 \mathrm{pptv}$ and $\sim 5$ pptv, respectively. The correlation between observed and predicted $\mathrm{HO}_{2}+\mathrm{RO}_{2}$ and $\mathrm{OH}$ from the $\mathrm{BM}_{-} \mathrm{BrO}_{\mathrm{CIMS}}$ slightly improved relative to the $\mathrm{BM}$. The model incorporating bromine chemistry brought the average hourly $\mathrm{OH}$ and $\mathrm{HO}_{2}+\mathrm{RO}_{2}$ predictions closer to the observations in 2008 . This indicates that $\mathrm{BrO}$ at Summit impacted the $\mathrm{HO}_{\mathrm{x}}$ levels, although most of the discrepancies between observations and models cannot be explained by the influence of detected $\mathrm{BrO}$. High levels of RGM were found to be coincident with the significant under predictions of $\mathrm{OH}$, and exclusion of high RGM periods significantly increased the agreement 
between predicted and observed $\mathrm{OH}$. This is consistent with bromine chemistry and potentially other chemistry leading to elevated RGM and impacting the production $\mathrm{OH}$ from $\mathrm{HO}_{2}$ and $\mathrm{RO}_{2}$. Enhanced snow photochemistry producing $\mathrm{H}_{2} \mathrm{O}_{2}$, $\mathrm{CH}_{2} \mathrm{O}$ and potentially other radical precursors at higher temperature may have contributed to the larger discrepancy between predicted and observed $\mathrm{HO}_{\mathrm{x}}$ in summer 2008 .

Acknowledgements. This work is financially supported by NSF GEO ATM Tropospheric Chemistry program (Grant ATM0612279:002). We thank NSF OPP, CH2MHill Polar Services, and the 109th Air National Guard for logistical support. We also thank Greenland Home rule for permission to work at Summit.

Edited by: J. Abbatt

\section{References}

Ariya, P. A., Khalizov, A., and Gidas, A.: Reactions of gaseous mercury with atomic and molecular halogens: Kinetics, product studies, and atmospheric implications, J. Phys. Chem. A, 106, 7310-7320, doi:10.1021/jp020719o, 2002.

Bloss, W. J., Lee, J. D., Heard, D. E., Salmon, R. A., Bauguitte, S. J.-B., Roscoe, H. K., and Jones, A. E.: Observations of $\mathrm{OH}$ and $\mathrm{HO}_{2}$ radicals in coastal Antarctica, Atmos. Chem. Phys., 7, 4171-4185, doi:10.5194/acp-7-4171-2007, 2007.

Bloss, W. J., Camredon, M., Lee, J. D., Heard, D. E., Plane, J. M. C., Saiz-Lopez, A., Bauguitte, S. J.-B., Salmon, R. A., and Jones, A. E.: Coupling of $\mathrm{HO}_{\mathrm{x}}, \mathrm{NO}_{\mathrm{x}}$ and halogen chemistry in the antarctic boundary layer, Atmos. Chem. Phys., 10, 1018710209, doi:10.5194/acp-10-10187-2010, 2010.

Brooks, S., Arimoto, R., Lindberg, S., and Southworth, G.: Antarctic polar plateau snow surface conversion of deposited oxidized mercury to gaseous elemental mercury with fractional long-term burial, Atmos. Environ., 42, 2877-2884, doi:10.1016/j.atmosenv.2007.05.029, 2008.

Brooks, S., Moore, C., Lew, D., Lefer, B., Huey, G., and Tanner, D.: Temperature and sunlight controls of mercury oxidation and deposition atop the Greenland ice sheet, Atmos. Chem. Phys. Discuss., 11, 3663-3691, doi:10.5194/acpd-11-3663-2011, 2011.

Chen, G., Davis, D., Crawford, J., Nowak, J. B., Eisele, F., Mauldin, R. L., Tanner, D., Buhr, M., Shetter, R., Lefer, B., Arimoto, R., Hogan, A., and Blake, D.: An investigation of South Pole $\mathrm{HO}_{\mathrm{x}}$ chemistry: Comparison of model results with ISCAT observations, Geophys. Res. Lett., 28, 3633-3636, 2001.

Chen, G., Davis, D., Crawford, J., Hutterli, L. M., Huey, L. G., Slusher, D., Mauldin, L., Eisele, F., Tanner, D., Dibb, J., Buhr, M., McConnell, J., Lefer, B., Shetter, R., Blake, D., Song, C. H., Lombardi, K., and Arnoldy, J.: A reassessment of $\mathrm{HO}_{\mathrm{x}}$ South Pole chemistry based on observations recorded during ISCAT 2000, Atmos. Environ., 38, 5451-5461, doi:10.1016/j.atmosenv.2003.07.018, 2004.

Chen, G., Huey, L. G., Crawford, J. H., Olson, J. R., Hutterli, M. A., Sjostedt, S., Tanner, D., Dibb, J., Lefer, B., Blake, N., Davis, D., and Stohl, A.: An assessment of the polar $\mathrm{HO}_{\mathrm{x}}$ photochemical budget based on 2003 Summit Greenland field observations, Atmos. Environ., 41, 7806-7820, doi:10.1016/j.atmosenv.2007.06.014, 2007.
Crawford, J. H., Davis, D. D., Chen, G., Buhr, M., Oltmans, S., Weller, R., Mauldin, L., Eisele, F., Shetter, R., Lefer, B., Arimoto, R., and Hogan, A.: Evidence for photochemical production of ozone at the South Pole surface, Geophys. Res. Lett., 28, 3641-3644, 2001.

Davis, D., Nowak, J. B., Chen, G., Buhr, M., Arimoto, R., Hogan, A., Eisele, F., Mauldin, L., Tanner, D., Shetter, R., Lefer, B., and McMurry, P.: Unexpected high levels of NO observed at South Pole, Geophys. Res. Lett., 28, 3625-3628, 2001.

Dibb, J. E. and Jaffrezo, J. L.: Air-snow exchange investigations at Summit, Greenland: An overview, J. Geophys. Res.-Ocean., 102, 26795-26807, 1997.

Dibb, J. E., Arsenault, M., Peterson, M. C., and Honrath, R. E.: Fast nitrogen oxide photochemistry in Summit, Greenland snow, Atmos. Environ., 36, 2501-2511, 2002.

Dibb, J. E., Huey, L. G., Slusher, D. L., and Tanner, D. J.: Soluble reactive nitrogen oxides at South Pole during ISCAT 2000, Atmos. Environ., 38, 5399-5409, doi:10.1016/j.atmosenv.2003.01.001, 2004.

Donohoue, D. L., Bauer, D., Cossairt, B., and Hynes, A. J.: Temperature and pressure dependent rate coefficients for the reaction of $\mathrm{Hg}$ with $\mathrm{Br}$ and the reaction of $\mathrm{Br}$ with $\mathrm{Br}$ : A pulsed laser photolysis-pulsed laser induced fluorescence study, J. Phys. Chem. A, 110, 6623-6632, doi:10.1021/jp054688j, 2006.

Edwards, G. D., Cantrell, C. A., Stephens, S., Hill, B., Goyea, O., Shetter, R. E., Mauldin, R. L., Kosciuch, E., Tanner, D. J., and Eisele, F. L.: Chemical ionization mass spectrometer instrument for the measurement of tropospheric $\mathrm{HO}_{2}$ and $\mathrm{RO}_{2}$, Anal. Chem., 75, 5317-5327, doi:10.1021/ac034402b, 2003.

Faïn, X., Ferrari, C. P., Dommergue, A., Albert, M., Battle, M., Arnaud, L., Barnola, J.-M., Cairns, W., Barbante, C., and Boutron, C.: Mercury in the snow and firn at Summit Station, Central Greenland, and implications for the study of past atmospheric mercury levels, Atmos. Chem. Phys., 8, 3441-3457, doi:10.5194/acp-8-3441-2008, 2008.

Grannas, A. M., Jones, A. E., Dibb, J., Ammann, M., Anastasio, C., Beine, H. J., Bergin, M., Bottenheim, J., Boxe, C. S., Carver, G., Chen, G., Crawford, J. H., Dominé, F., Frey, M. M., Guzmán, M. I., Heard, D. E., Helmig, D., Hoffmann, M. R., Honrath, R. E., Huey, L. G., Hutterli, M., Jacobi, H. W., Klán, P., Lefer, B., McConnell, J., Plane, J., Sander, R., Savarino, J., Shepson, P. B., Simpson, W. R., Sodeau, J. R., von Glasow, R., Weller, R., Wolff, E. W., and Zhu, T.: An overview of snow photochemistry: evidence, mechanisms and impacts, Atmos. Chem. Phys., 7, 4329-4373, doi:10.5194/acp-7-4329-2007, 2007.

Haman, C., Lefer, B., Dibb, J. E., and Clements, C.: Evidence for a mid- to upper-tropospheric source of bromide reaching Summit, Atmos. Chem. Phys. Discuss., in preparation, 2011.

Hammer, C. U., Clausen, H. B., and Dansgaard, W.: Greenland icesheet evidence of post-glacial volcanism and its climatic impact, Nature, 288, 230-235, 1980.

Hausmann, M. and Platt, U.: Spectroscopic measurement of bromine oxide and ozone in the high Arctic during polar sunrise experiment 1992, J. Geophys. Res.-Atmos., 99, 25399-25413, 1994.

Helmig, D., Boulter, J., David, D., Birks, J. W., Cullen, N. J., Steffen, K., Johnson, B. J., and Oltmans, S. J.: Ozone and meteorological Summit, Greenland, boundary-layer conditions at during 3-21 June 2000, Atmos. Environ., 36, 2595-2608, 2002. 
Helmig, D., Johnson, B. J., Warshawsky, M., Morse, T., Neff, W. D., Eisele, F., and Davis, D. D.: Nitric oxide in the boundarylayer at South Pole during the Antarctic Tropospheric Chemistry Investigation (ANTCI), Atmos. Environ., 42, 2817-2830, doi:10.1016/j.atmosenv.2007.03.061, 2008.

Honrath, R. E., Peterson, M. C., Guo, S., Dibb, J. E., Shepson, P. B., and Campbell, B.: Evidence of $\mathrm{NO}_{\mathrm{x}}$ production within or upon ice particles in the Greenland snowpack, Geophys. Res. Lett., 26, 695-698, 1999.

Honrath, R. E., Lu, Y., Peterson, M. C., Dibb, J. E., Arsenault, M. A., Cullen, N. J., and Steffen, K.: Vertical fluxes of $\mathrm{NO}_{\mathrm{x}}$, HONO, and $\mathrm{HNO}_{3}$ above the snowpack at Summit, Greenland, Atmos. Environ., 36, 2629-2640, 2002.

Huey, L. G., Hanson, D. R., and Howard, C. J.: Reactions of $\mathrm{SF}_{6}^{-}$ and $\mathrm{I}^{-}$with atmospheric trace gases, J. Phys. Chem., 99, 50015008, 1995.

Huey, L. G., Tanner, D. J., Slusher, D. L., Dibb, J. E., Arimoto, R., Chen, G., Davis, D., Buhr, M. P., Nowak, J. B., Mauldin, R. L., Eisele, F. L., and Kosciuch, E.: CIMS measurements of $\mathrm{HNO}_{3}$ and $\mathrm{SO}_{2}$ at the South Pole during ISCAT 2000, Atmos. Environ., 38, 5411-5421, doi:10.1016/j.atmosenv.2004.04.037, 2004.

Hutterli, M. A., Rothlisberger, R., and Bales, R. C.: Atmosphereto-snow-to-firn transfer studies of HCHO at Summit, Greenland, Geophys. Res. Lett., 26, 1691-1694, 1999.

Hutterli, M. A., McConnell, J. R., Stewart, R. W., Jacobi, H. W., and Bales, R. C.: Impact of temperature-driven cycling of hydrogen peroxide $\left(\mathrm{H}_{2} \mathrm{O}_{2}\right)$ between air and snow on the planetary boundary layer, J. Geophys. Res.-Atmos., 106, 15395-15404, 2001.

Hutterli, M. A., McConnell, J. R., Chen, G., Bales, R. C., Davis, D. D., and Lenschow, D. H.: Formaldehyde and hydrogen peroxide in air, snow and interstitial air at South Pole, Atmos. Environ., 38, 5439-5450, doi:10.1016/j.atmosenv.2004.06.003, 2004.

Jefferson, A., Tanner, D. J., Eisele, F. L., Davis, D. D., Chen, G., Crawford, J., Huey, J. W., Torres, A. L., and Berresheim, H.: $\mathrm{OH}$ photochemistry and methane sulfonic acid formation in the coastal Antarctic boundary layer, J. Geophys. Res.-Atmos., 103, 1647-1656, 1998.

Jones, A. E., Wolff, E. W., Salmon, R. A., Bauguitte, S. J.-B., Roscoe, H. K., Anderson, P. S., Ames, D., Clemitshaw, K. C., Fleming, Z. L., Bloss, W. J., Heard, D. E., Lee, J. D., Read, K. A., Hamer, P., Shallcross, D. E., Jackson, A. V., Walker, S. L., Lewis, A. C., Mills, G. P., Plane, J. M. C., Saiz-Lopez, A., Sturges, W. T., and Worton, D. R.: Chemistry of the Antarctic Boundary Layer and the Interface with Snow: an overview of the CHABLIS campaign, Atmos. Chem. Phys., 8, 3789-3803, doi:10.5194/acp-8-3789-2008, 2008.

Kim, S., Huey, L. G., Stickel, R. E., Tanner, D. J., Crawford, J. H., Olson, J. R., Chen, G., Brune, W. H., Ren, X., Lesher, R., Wooldridge, P. J., Bertram, T. H., Perring, A., Cohen, R. C., Lefer, B. L., Shetter, R. E., Avery, M., Diskin, G., and Sokolik, I.: Measurement of $\mathrm{HO}_{2} \mathrm{NO}_{2}$ in the free troposphere during the intercontinental chemical transport experiment - North America 2004, J. Geophys. Res.-Atmos., 112, D12s01, doi:10.1029/2006jd007676, 2007.

Liao, J., Sihler, H., Huey, L. G., Neuman, J. A., Tanner, D. J., Friess, U., Platt, U., Flocke, F. M., Orlando, P. B. Shepson, J. J., Beine, H. J., Weinheimer, A.J., Sjostedt, S. J., Nowak, J. B., Knapp, D. J., Staebler, R. M., Zheng, W., Sander, R., Hall, S. R., and Ullman, K.: A comparison of Arctic BrO measurements by chemical ionization mass spectrometry (CIMS) and long pathdifferential optical absorption spectroscopy (LP-DOAS), J. Geophys. Res., 116, D00R02, doi:10.1029/2010JD014788, 2011 a.

Liao, J., Huey, L.G., Tanner, D. J., Flocke, F. M., Orlando, J. J., Neuman, J.A., Nowak, J. B., Weinheimer A. J., Hall, S. R., Smith, J. N., Fried, A., Staebler, R. M., Wang, Y., Koo, J.-H., Cantrell, C. A., Weibring, P., Walega, J., Knapp, D. J., Shepson, P. B., and Stephens, C. R.: Observed and modeled inorganic bromine $\left(\mathrm{HOBr}, \mathrm{BrO}\right.$, and $\left.\mathrm{Br}_{2}\right)$ speciation at Barrow, $\mathrm{AK}$ in spring 2009, J. Geophys. Res, in review, 2011 b.

Mahajan, A. S., Oetjen, H., Lee, J. D., Saiz-Lopez, A., McFiggans, G. B., and Plane, J. M. C.: High bromine oxide concentrations in the semi-polluted boundary layer, Atmos. Environ., 43, 38113818, doi:10.1016/j.atmosenv.2009.05.033, 2009.

Mao, J., Jacob, D. J., Evans, M. J., Olson, J. R., Ren, X., Brune, W. H., St Clair, J. M., Crounse, J. D., Spencer, K. M., Beaver, M. R., Wennberg, P. O., Cubison, M. J., Jimenez, J. L., Fried, A., Weibring, P., Walega, J. G., Hall, S. R., Weinheimer, A. J., Cohen, R. C., Chen, G., Crawford, J. H., McNaughton, C., Clarke, A. D., Jaegle, L., Fisher, J. A., Yantosca, R. M., Le Sager, P., and Carouge, C.: Chemistry of hydrogen oxide radicals $\left(\mathrm{HO}_{\mathrm{x}}\right)$ in the Arctic troposphere in spring, Atmos. Chem. Phys., 10, 58235838, doi:10.5194/acp-10-5823-2010, 2010.

Mauldin, R. L., Eisele, F. L., Tanner, D. J., Kosciuch, E., Shetter, R., Lefer, B., Hall, S. R., Nowak, J. B., Buhr, M., Chen, G., Wang, P., and Davis, D.: Measurements of $\mathrm{OH}, \mathrm{H}_{2} \mathrm{SO}_{4}$, and MSA at the South Pole during ISCAT, Geophys. Res. Lett., 28, 3629-3632, 2001.

Mauldin, R. L., Kosciuch, E., Henry, B., Eisele, F. L., Shetter, R., Lefer, B., Chen, G., Davis, D., Huey, G., and Tanner, D.: Measurements of $\mathrm{OH}, \mathrm{HO}_{2}+\mathrm{RO}_{2}, \mathrm{H}_{2} \mathrm{SO}_{4}$, and MSA at the south pole during ISCAT 2000, Atmos. Environ., 38, 5423-5437, doi:10.1016/j.atmosenv.2004.06.031, 2004.

Mauldin, R., Kosciuch, E., Eisele, F., Huey, G., Tanner, D., Sjostedt, S., Blake, D., Chen, G., Crawford, J., and Davis, D.: South Pole Antarctica observations and modeling results: New insights on $\mathrm{HO}_{\mathrm{x}}$ radical and sulfur chemistry, Atmos. Environ., 44, 572-581, doi:10.1016/j.atmosenv.2009.07.058, 2010.

Mayewski, P. A. and Bender, M.: The GISP2 ice core record- paleoclimate highlights, Rev. Geophys., 33, 1287-1296, 1995.

Neuman, J. A., Nowak, J. B., Huey, L. G., Burkholder, J. B., Dibb, J. E., Holloway, J. S., Liao, J., Peischl, J., Roberts, J. M., Ryerson, T. B., Scheuer, E., Stark, H., Stickel, R. E., Tanner, D. J., and Weinheimer, A.: Bromine measurements in ozone depleted air over the Arctic Ocean, Atmos. Chem. Phys., 10, 6503-6514, doi:10.5194/acp-10-6503-2010, 2010.

Read, K. A., Mahajan, A. S., Carpenter, L. J., Evans, M. J., Faria, B. V. E., Heard, D. E., Hopkins, J. R., Lee, J. D., Moller, S. J., Lewis, A. C., Mendes, L., McQuaid, J. B., Oetjen, H., SaizLopez, A., Pilling, M. J., and Plane, J. M. C.: Extensive halogenmediated ozone destruction over the tropical Atlantic Ocean, Nature, 453, 1232-1235, doi:10.1038/nature07035, 2008.

Ren, X. R., Olson, J. R., Crawford, J. H., Brune, W. H., Mao, J. Q., Long, R. B., Chen, Z., Chen, G., Avery, M. A., Sachse, G. W., Barrick, J. D., Diskin, G. S., Huey, L. G., Fried, A., Cohen, R. C., Heikes, B., Wennberg, P. O., Singh, H. B., Blake, D. R., and Shetter, R. E.: $\mathrm{HO}_{\mathrm{x}}$ chemistry during INTEX-A 2004: Observation, model calculation, and comparison with previous studies, J. Geophys. Res.-Atmos., 113, 
D05310, doi:10.1029/2007jd009166, 2008.

Ryerson, T. B., Williams, E. J., and Fehsenfeld, F. C.: An efficient photolysis system for fast-response $\mathrm{NO}_{2}$ measurements, J. Geophys. Res.-Atmos., 105, 26447-26461, 2000.

Saiz-Lopez, A., Shillito, J. A., Coe, H., and Plane, J. M. C.: Measurements and modelling of $\mathrm{I}_{2}, \mathrm{IO}, \mathrm{OIO}, \mathrm{BrO}$ and $\mathrm{NO}_{3}$ in the mid-latitude marine boundary layer, Atmos. Chem. Phys., 6, 1513-1528, doi:10.5194/acp-6-1513-2006, 2006.

Saiz-Lopez, A., Mahajan, A. S., Salmon, R. A., Bauguitte, S. J. B., Jones, A. E., Roscoe, H. K., and Plane, J. M. C.: Boundary layer halogens in coastal Antarctica, Science, 317, 348-351, doi:10.1126/science.1141408, 2007.

Sander, S. P, Friedl, R. R., Golden, D. M., Kurylo, M. J., Moortgat, Keller-Rudek, H., G. K., Wine, P. H., Ravishankara, A. R., Kolb, C. E., Molina, M. J., Finlayson-Pitts, B., Huie, R. E., and Orkin, V. L: Chemical Kinetics and Photochemical Data for Use in Atmospheric Studies Evaluation Number 15, JPL Publ. 06-2, NASA Jet Propulsion Laboratory, California Institute of Technology, Pasadena, CA, 2006.

Shetter, R. E. and Muller, M.: Photolysis frequency measurements using actinic flux spectroradiometry during the PEM-Tropics mission: Instrumentation description and some results, J. Geophys. Res.-Atmos., 104, 5647-5661, 1999.

Sjostedt, S. J.: Investigation of photochemistry at high latitudes: comparison of model predictions to measurements of short lived species, Ph.D thesis, Georgia Institute of Technology, Atlanta, 2006.

Sjostedt, S. J., Huey, L. G., Tanner, D. J., Peischl, J., Chen, G., Dibb, J. E., Lefer, B., Hutterli, M. A., Beyersdorf, A. J., Blake, N. J., Blake, D. R., Sueper, D., Ryerson, T., Burkhart, J., and Stohl, A.: Observations of hydroxyl and the sum of peroxy radicals at Summit, Greenland during summer 2003, Atmos. Environ., 41, 5122-5137, doi:10.1016/j.atmosenv.2006.06.065, 2007.

Slusher, D. L., Pitteri, S. J., Haman, B. J., Tanner, D. J., and Huey, L. G.: A chemical ionization technique for measurement of pernitric acid in the upper troposphere and the polar boundary layer, Geophys. Res. Lett., 28, 3875-3878, 2001.

Slusher, D. L., Huey, L. G., Tanner, D. J., Chen, G., Davis, D. D., Buhr, M., Nowak, J. B., Eisele, F. L., Kosciuch, E., Mauldin, R. L., Lefer, B. L., Shetter, R. E., and Dibb, J. E.: Measurements of pernitric acid at the South Pole during ISCAT 2000, Geophys. Res. Lett., 29, 2011, doi:10.1029/2002g1015703, 2002.

Steffen, A., Douglas, T., Amyot, M., Ariya, P., Aspmo, K., Berg, T., Bottenheim, J., Brooks, S., Cobbett, F., Dastoor, A., Dommergue, A., Ebinghaus, R., Ferrari, C., Gardfeldt, K., Goodsite, M. E., Lean, D., Poulain, A. J., Scherz, C., Skov, H., Sommar, J., and Temme, C.: A synthesis of atmospheric mercury depletion event chemistry in the atmosphere and snow, Atmos. Chem. Phys., 8, 1445-1482, doi:10.5194/acp-8-1445-2008, 2008.
Streit, G. E.: Negative-ion chemistry and the electron-affinity of $\mathrm{SF}_{6}$, J. Chem. Phys., 77, 826-833, 1982.

Stutz, J. and Platt, U.: Improving long-path differential optical absorption spectroscopy with a quartz-fiber mode mixer, Appl. Optics, 36, 1105-1115, 1997.

Stutz, J., Oh, H. J., Whitlow, S. I., Anderson, C., Dibbb, J. E., Flynn, J. H., Rappengluck, B., and Lefer, B.: Simultaneous DOAS and mist-chamber IC measurements of HONO in Houston, TX, Atmos. Environ., 44, 4090-4098, doi:10.1016/j.atmosenv.2009.02.003, 2010.

Stutz, J., Thomas, J. L., Hurlock, S. C., Schneider, M., von Glasow, R., Piot, M., Gorham, K., Burkhart, J. F., Ziemba, L., Dibb, J. E., and Lefer, B. L.: Longpath DOAS observations of surface BrO at Summit, Greenland, Atmos. Chem. Phys. Discuss., 11, 6707-6736, doi:10.5194/acpd-11-6707-2011, 2011.

Swanson, A. L., Blake, N. J., Dibb, J. E., Albert, M. R., Blake, D. R., and Rowland, F. S.: Photochemically induced production of $\mathrm{CH}_{3} \mathrm{Br}, \mathrm{CH}_{3} \mathrm{I}, \mathrm{C}_{2} \mathrm{H}_{5} \mathrm{I}$, ethene, and propene within surface snow at Summit, Greenland, Atmos. Environ., 36, 2671-2682, 2002.

Tanner, D. J., Jefferson, A., and Eisele, F. L.: Selected ion chemical ionization mass spectrometric measurement of $\mathrm{OH}, \mathrm{J}$. Geophys. Res.-Atmos., 102, 6415-6425, 1997.

Thomas, J. L., Stutz, J., Lefer, B., Huey, L. G., Toyota, K., Dibb, J. E., and von Glasow, R.: Modeling chemistry in and above snow at Summit, Greenland - Part 1: Model description and results, Atmos. Chem. Phys., 11, 4899-4914, doi:10.5194/acp-11-48992011, 2011.

Tuckermann, M., Ackermann, R., Golz, C., LorenzenSchmidt, H., Senne, T., Stutz, J., Trost, B., Unold, W., and Platt, U.: DOASobservation of halogen radical-catalysed arctic boundary layer ozone destruction during the ARCTOC-campaigns 1995 and 1996 in Ny-Alesund, Spitsbergen, Tellus B, 49, 533-555, 1997.

Wachsmuth, M., Gäggeler, H. W., von Glasow, R., and Ammann, M.: Accommodation coefficient of $\mathrm{HOBr}$ on deliquescent sodium bromide aerosol particles, Atmos. Chem. Phys., 2, 121131, doi:10.5194/acp-2-121-2002, 2002.

Yang, J., Honrath, R. E., Peterson, M. C., Dibb, J. E., Sumner, A. L., Shepson, P. B., Frey, M., Jacobi, H. W., Swanson, A., and Blake, N.: Impacts of snowpack emissions on deduced levels of $\mathrm{OH}$ and peroxy radicals at Summit, Greenland, Atmos. Environ., 36, 2523-2534, 2002.

Ziemba, L. D., Dibb, J. E., Griffin, R. J., Huey, L. G., and Beckman, P.: Observations of particle growth at a remote, Arctic site, Atmos. Environ., 44, 1649-1657, doi:10.1016/j.atmosenv.2010.01.032, 2010. 